\title{
Satellite measurement based estimates of decadal changes in European nitrogen oxides emissions
}

\author{
I. B. Konovalov ${ }^{1,2}$, M. Beekmann ${ }^{2}$, J. P. Burrows ${ }^{3}$, and A. Richter ${ }^{3}$ \\ ${ }^{1}$ Institute of Applied Physics, Russian Academy of Sciences, Nizhniy Novgorod, Russia \\ ${ }^{2}$ Laboratoire Inter-Universitaire de Systèmes Atmosphériques, CNRS, Créteil, France \\ ${ }^{3}$ Institute of Environmental Physics and Remote Sensing, IUP/IFE, University of Bremen, Bremen, Germany \\ Received: 22 November 2007 - Published in Atmos. Chem. Phys. Discuss.: 5 February 2008 \\ Revised: 18 April 2008 - Accepted: 6 May 2008 - Published: 19 May 2008
}

\begin{abstract}
Long-term satellite measurements of nitrogen dioxide in the troposphere are used in combination with a continental scale air quality model in order to verify and improve available estimates of multi-annual changes of emissions of nitrogen oxides $\left(\mathrm{NO}_{\mathrm{x}}\right)$ in Europe and the Mediterranean area between 1996 and 2005. As a result, a measurement-based data set of $\mathrm{NO}_{\mathrm{x}}$ emissions on a $1^{\circ}$ by $1^{\circ}$ grid and averaged over summer months is elaborated.

The results are compared with emission data based on the EMEP emission inventory. Our data are in agreement with the EMEP estimates suggesting a general decline in the level of $\mathrm{NO}_{\mathrm{x}}$ emissions in Western and Central European countries (France, Germany, Great Britain and Poland). Over Southern Europe and for shipping emissions, neutral to positive trends are found both for the inverted and bottom-up emissions. In contrast, considerable differences between both data sets are found in some other countries. In particular, significant negative trends instead of the positive ones in the "bottomup" inventory are found for the Balkan countries, Russia and Turkey. The $\mathrm{NO}_{\mathrm{x}}$ emission trends derived from satellite measurements demonstrate larger spatial heterogeneity than those calculated with the EMEP data, especially in Russia and Ukraine.
\end{abstract}

The obtained estimates of the decadal trends in $\mathrm{NO}_{\mathrm{x}}$ emissions for Great Britain are found to be consistent with independent data from the U.K. Automatic Urban and Rural Network (AURN). It is also found that using our emission estimates yields better agreement of model calculations with near-surface ozone measurements of the European EMEP network.

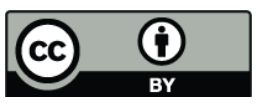

Correspondence to: I. B. Konovalov (konov@appl.sci-nnov.ru)

\section{Introduction}

It is widely recognized that the ability of atmospheric models to represent the current state and to predict possible future changes of the chemical composition of the atmosphere depends strongly on the quality of available information about sources (emissions) of atmospheric pollutants. One promising approach for the validation of the available emission inventories and for generation of improved emission data involves inverse modelling of sources of atmospheric gases (see, e.g., Enting, 2002). In this method, observational data are used as constraints to emission parameters, which are used as input for an atmospheric model. The method implicitly assumes that the model comprises an adequate description of the chemical and physical processes, which determine the amount and distribution of the species in the atmosphere.

A strong impetus for the further development of atmospheric inverse modelling studies has been provided by recent remarkable progress in satellite measurements of the composition of the lower atmosphere. The tropospheric column amounts of such important trace gases as nitrogen dioxide, $\mathrm{NO}_{2}$, sulphur dioxide, $\mathrm{SO}_{2}$, carbon monoxide, $\mathrm{CO}$, methane, $\mathrm{CH}_{4}$, formaldehyde, $\mathrm{HCHO}$, glyoxal, $\mathrm{CHOCHO}$, and methanol, $\mathrm{CH}_{3} \mathrm{OH}$, derived from almost global satellite measurements (e.g., Eisinger and Burrows, 1998; Velders et al., 2001; Palmer et al., 2001; Richter and Burrows, 2002; Buchwitz et al., 2004; Bowman, et al., 2006; Wittrock et al., 2006; Dufour et al., 2006) contain valuable information about the sources, transport and sinks of these gases. The retrieved tropospheric data products have already been used in several studies aimed at obtaining better estimates of emissions of respective gases. In particular, tropospheric $\mathrm{NO}_{2}$ columns derived from the GOME and SCIAMACHY measurements (Burrows et al., 1999; Bovensmann et al., 1999) have been used for the estimation of total $\mathrm{NO}_{\mathrm{x}}$ emissions

Published by Copernicus Publications on behalf of the European Geosciences Union. 
on the global scale (Leue et al., 2001; Martin et al., 2003, 2006; Müller and Stavrakou, 2005) and on the regional scale (Konovalov et al., 2006a, b), as well as for estimations of $\mathrm{NO}_{\mathrm{x}}$ emissions from different kinds of sources such as lightning (Boersma et al., 2005; Beirle et al., 2006; Martin et al., 2007), ships (Beirle et al., 2004; Richter et al., 2004) or soils (Jaegle et al., 2004; Bertram et al., 2005; Wang et al., 2007). Satellite measurements have also been used to improve emission estimates for carbon monoxide (Pétron et al., 2004; Yurganov et al., 2005; Stavrakou and Müller, 2006) and isoprene (Palmer et al., 2003; Millet et al., 2006).

The $\mathrm{NO}_{2}$ time series from satellite measurements have also been used to study long-term changes in anthropogenic emissions of nitrogen oxides $\left(\mathrm{NO}_{\mathrm{x}}\right)$. In particular, Richter et al. (2005) found a substantial decrease of $\mathrm{NO}_{2}$ column amounts over some areas of Europe and the USA in a decadal period from 1996 to 2005, but highly significant increase over the industrial areas of China. They argued that the increase of $\mathrm{NO}_{2}$ column amount over China is a result of corresponding increase in $\mathrm{NO}_{\mathrm{x}}$ emissions. The increase of $\mathrm{NO}_{2}$ column amounts over Eastern China during the same period was independently reported by van der A et al. (2006). Kim et al. (2006) used the same satellite measurements to confirm reduction of $\mathrm{NO}_{\mathrm{x}}$ emission from US power plants. Note that although multi-annual changes in emissions of atmospheric gases can, in principle, be estimated from analysis of groundbased measurements (see e.g., Dentener et al., 2003; Bousquet et al., 2000), the near-global satellite measurements are indispensable in areas where monitoring networks are sparse or absent, such as in many Eastern European and Asian countries.

In this study, we use data of the multi-year measurements performed by the GOME and SCIAMACHY satellite instruments in order to estimate decadal changes in $\mathrm{NO}_{\mathrm{x}}$ emissions in Europe and the Mediterranean and to compare with and validate the data of emission inventories, which are based on the "bottom-up" approach. In order to take into account chemical transformations and the transport of emitted nitrogen oxides as well as natural variability of tropospheric $\mathrm{NO}_{2}$ column amounts, we combine the satellite data with calculations performed by a continental scale chemistry transport model (CTM) in the framework of an inverse modelling scheme. This technique is considered to be complementary to the earlier papers deriving emission trends directly from satellite measurements (Richter et al., 2005; Kim et al., 2006), because it attempts to take explicitly into account the role of the chemistry and transport in determining the relationship between $\mathrm{NO}_{2}$ columns and $\mathrm{NO}_{\mathrm{x}}$ emissions. Besides, the inverse modelling approach allows estimating emissions on a regular grid, so that these estimates can readily be used in other modelling applications. In contrast to a more common inverse modelling approach, where the improved emission estimates in each grid cell (or region) are searched for as deviations from corresponding a priori (bottom-up) estimates, our estimates of $\mathrm{NO}_{\mathrm{x}}$ emission changes in each grid cell are almost independent from any prior knowledge. Such an approach strongly reduces the role of "subjective judgement" regarding uncertainties (frequently unknown) in available emission inventory data as well as in measurement and simulated data and allows our estimates to be considered as a measurement-based alternative to respective data from emission cadastres. Note that the focus in this study is the determination of relative inter-annual changes in $\mathrm{NO}_{\mathrm{x}}$ emissions and not the estimation of absolute values of emissions, which is a more common goal in inverse modelling studies. Accurate independent estimates of past changes in $\mathrm{NO}_{\mathrm{x}}$ emissions provide new opportunities for the evaluation of the efficiency of air pollution control measures, the assessment of uncertainties in emission cadastres, and the test of the ability of chemistry transport models to reproduce past and predict future changes in atmospheric composition.

The manuscript is organised as follows. The data used for our analysis are introduced in Sect. 2. Our inversion scheme is described in Sect. 3. The results of the inversion and their validation are discussed in Sect. 4. Sect. 5 summarises the results of this study.

\section{Measurement and model data}

\subsection{Satellite data}

Tropospheric $\mathrm{NO}_{2}$ columns derived from satellite measurements by IUP, University of Bremen, are used. Seven years (1996-2002) of the GOME measurements (Burrows et al., 1999) are complemented with three years (2003-2005) of the SCIAMACHY measurements (Bovensmann et al., 1999). The GOME and SCIAMACHY instruments provide measurements of $\mathrm{NO}_{2}$ columns with a horizontal resolution of $320 \times 40 \mathrm{~km}^{2}$ and $60 \times 30 \mathrm{~km}^{2}$, global coverage at the equator being achieved in 3 and $6 \mathrm{~d}$, respectively. We use the same data-products for tropospheric $\mathrm{NO}_{2}$ columns derived from satellite measurements and analysed earlier in Richter et al. (2005), where a general description of the retrieval method can be found. The same data were also used by Kim et al. (2006).

A pre-processing stage (specific for this study) includes (1) projection of daily data for tropospheric $\mathrm{NO}_{2}$ columns onto a $1^{\circ} \times 1^{\circ}$ grid, (2) averaging of all data for three summer months (June-August) of each year, and (3) deconvolution of the data obtained from the GOME measurements. In this study we consider only summertime measurements because of prevailing cloudy conditions in Eastern Europe during the cold season. In addition, the relatively short lifetime of $\mathrm{NO}_{\mathrm{x}}$ in the summer troposphere, which is determined in large part by its reaction with $\mathrm{OH}$ and the night-time removal of $\mathrm{N}_{2} \mathrm{O}_{5}$ via deposition at the surface, facilitates the inversion procedure.

The deconvolution of the GOME $\mathrm{NO}_{2}$ data is needed to avoid systematic "jumps" in the time series of the gridded 
$\mathrm{NO}_{2}$ columns between 2002 and 2003 between the lower resolution GOME data and the higher spatial resolution SCIAMACHY data. The method of deconvolution of the GOME data is very similar to the one suggested in our earlier study (Konovalov et al., 2006a). The basis of this approach is to superimpose the spatial structure of the $\mathrm{NO}_{2}$ columns derived from the SCIAMACHY measurements over the spatial structure of the $\mathrm{NO}_{2}$ columns derived from the GOME measurements. In this study, three-year averages of SCIAMACHY data for summer months were used. Uncertainties in our results which arise from poorer spatial resolution of the GOME data are estimated as discussed in Sect. 3.4.

By comparing overlapping data derived from the GOME and SCIAMACHY measurements in the period from August 2002 to November 2003, Richter et al. (2005) clearly demonstrated the consistency of $\mathrm{NO}_{2}$ column amounts obtained from these instruments and averaged over Eastern China, as well as the absence of any significant systematic drift in the measurements (e.g., as a result of the ageing of the GOME instrument). In order to make sure that the consistency of the GOME and SCIAMACHY data is also preserved for each grid cell of our model domain (see Sect. 2.4), we performed an additional simple test. Specifically, we considered the quadratic differences between $\mathrm{NO}_{2}$ columns in the neighboring years $(n, n-1)$ in the same grid cell $i$ and averaged these differences over the whole grid:

$D^{n}=\left[\sum_{i=1}^{N}\left(c_{i}^{n}-c_{i}^{n-1}\right)^{2}\right]^{1 / 2}$

where $N$ is the total number of grid cells considered. Values of $D^{n}$ are shown in Fig. 1. If there was a strong systematic difference between the GOME and SCIAMACHY data, then the differences between $\mathrm{NO}_{2}$ columns for the years 2003 for which only SCIAMACHY data were available and 2002 for which the GOME data are used, would be exceptionally large. There is no evidence of strong systematic bias which would be comparable with the typical level (about $5 \times 10^{14} \mathrm{molec} / \mathrm{cm}^{2}$ ) of inter-annual fluctuations in the $\mathrm{NO}_{2}$ column amounts. These fluctuations are caused by natural variability of $\mathrm{NO}_{2}$ in the troposphere, inter-annual changes in $\mathrm{NO}_{\mathrm{x}}$ emissions and random uncertainties in the retrieved data.

\subsection{Data of ground-based measurements}

In order to validate results of the inverse modelling, the following measurements have been used: (i) measurements of near surface concentrations of nitrogen oxides from the United Kingdom Automatic Urban and Rural Network (AURN) (www.airquality.co.uk) between 1996 and 2005 and (ii) measurements of ozone at the EMEP network (http: //www.nilu.no/projects/ccc/) available for all years considered except 2005. The raw hourly data have been processed to yield the seasonally averaged (over the summer months)

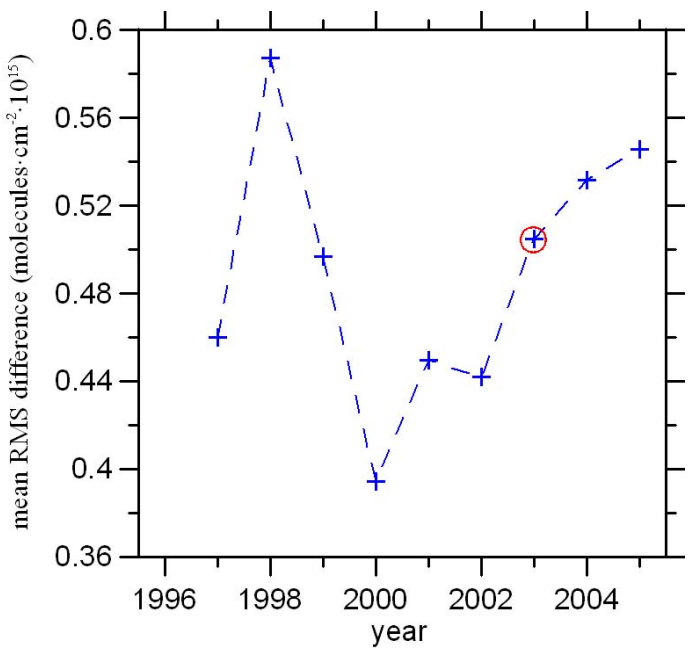

Fig. 1. A test of consistency of tropospheric $\mathrm{NO}_{2}$ columns derived from the GOME (1996-2002) and SCIMACHY (2003-2005) measurements. The figure shows the RMS differences between $\mathrm{NO}_{2}$ columns in the neighboring years. The differences were calculated for each grid cell and averaged over the whole model's grid. The transition between the GOME and SCIAMACHY data between 2002 and 2003 (red circle) does not indicate any exceptional change in the data.

daily mean $\mathrm{NO}_{\mathrm{x}}$ concentrations and to calculate the 90 percentile of the ozone concentration daily maximums. The data used in the study from the two networks were chosen by considering the criteria of availability, representativeness and quality of data. The high percentile of ozone concentrations have been chosen for this study because this characteristic is believed to be less sensitive to changes in background ozone level, which are not necessarily caused by changes in local emissions (e.g., Vautard et al., 2006). 21 stations from the AURN and 36 EMEP stations that provided data for at least 90 percent of the total number of days in each summer season are considered. The locations of the monitors are discussed below (see Sect. 4).

\section{3 "Bottom-up" emission inventories}

The anthropogenic emission data used in this study are based on the so-called "expert" annual data of the EMEP emission inventory (Vestreng et al., 2005) for the years 1996-2004. We have used the two versions of the expert data that were available at the EMEP web site (http://webdab.emep.int/) on a $0.5^{\circ} \times 0.5^{\circ}$ grid in autumn 2006 (before 30 November) and in spring 2007. As emission data were not available for the year 2005 a linear interpolation between the years 2004 and 2010 has been performed to generate the values for 2005 . For 2010 a "projection" has been used. The comparison of the older and newer versions of the emission data gives some idea about uncertainties in the bottom-up inventories and is helpful for validation of emission estimates obtained in this 

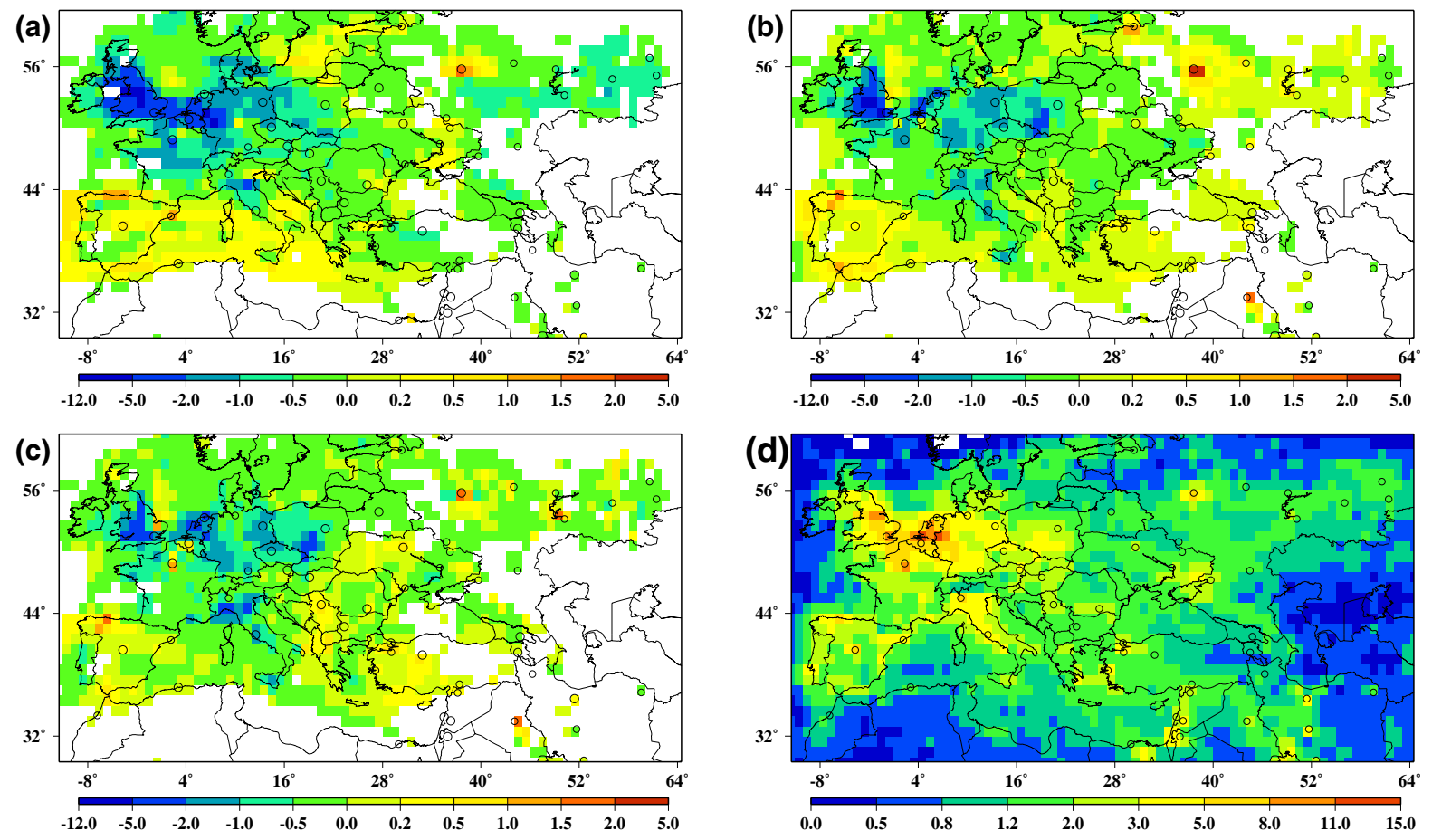

Fig. 2. Linear trends (molecules $\times \mathrm{cm}^{-2} \times \mathrm{yr}^{-1} \times 10^{14}$ ) over the decade from 1996 to 2005 in (a) the measured $\mathrm{NO}_{2}$ columns in comparison with the trends in the simulated $\mathrm{NO}_{2}$ columns obtained with the (b) "new" and (c) "old" EMEP data along with (d) magnitudes of the tropospheric $\mathrm{NO}_{2}$ columns (molecules $\times \mathrm{cm}^{-2} \times 10^{15}$ ) derived form the SCIAMACHY measurements in summer 2003 . The trends are shown only for those grid cells for which, according to our model calculations, the contribution of $\mathrm{NO}_{2}$ from anthropogenic sources is dominating the total tropospheric $\mathrm{NO}_{2}$ column amount.

study, particularly because more recent emission data are expected to be more accurate than the older ones. As it is shown below (see Sect. 4), the differences in trends between the two versions of the EMEP data are, in some cases, large. Unfortunately, an explanation for these differences has not yet been made publicly available.

Biogenic emissions of isoprene, terpenes and NO are parameterised as proposed by Simpson et al. (1999), using distributions of tree species on a country basis provided in their work and the inventory of NO soil emissions by Stohl et al. (1996). No inter-annual changes in biogenic NO emissions were specified.

\subsection{Simulated data}

To generate the simulated $\mathrm{NO}_{2}$ columns, the CHIMERE CTM was used (Schmidt et al., 2001). The model takes into account all important processes that determine the evolution of nitrogen oxides released into the atmosphere, such as gasphase reactions which define the chemical balance between $\mathrm{NO}_{\mathrm{x}}$ species and their transformation to nitric acid, dinitrogen pentoxide and organic nitrogen compounds; dry deposition and wet scavenging which are responsible for the removal of the reactive nitrogen compounds from the atmo- sphere; advective transport, eddy diffusion and deep convection. A detailed description of CHIMERE is available on the web at http://euler.lmd.polytechnique.fr/chimere/. The simulated $\mathrm{NO}_{2}$ columns were sampled consistently in space and time with the measurement-based daily $\mathrm{NO}_{2}$ columns. The same model was used also to simulate data for comparison with the measured near-surface concentrations of $\mathrm{NO}_{\mathrm{x}}$ and ozone.

In this study we use a spatial domain that covers all of Europe, the Mediterranean area and the Middle East with a horizontal resolution of $1^{\circ} \times 1^{\circ}$. The extension of CHIMERE beyond Western Europe is discussed in Konovalov et al. (2005). In this study, the standard model domain has also been extended in the vertical up to the $200 \mathrm{hPa}$ pressure level. The model runs were performed with 12 layers defined as hybrid coordinates. Meteorological input data were calculated off-line with horizontal resolution of $100 \times 100 \mathrm{~km}^{2}$ using the MM5 non-hydrostatic meso-scale model (http://www. mmm.ucar.edu/mm5/). MM5 was initialised with NCEP Reanalysis-2 data (http://www.cpc.ncep.noaa.gov/products/ wesley/ncep_data/). Lateral boundary conditions are prescribed using monthly average values of the climatological simulations by the second generation MOZART model 
(Horowitz et al., 2003). The other specific features of the model configuration are the same as described in Konovalov et al. (2005, 2006a).

CHIMERE was run independently for each summer season starting on 24 May with the same initial and boundary conditions. Although changes in atmospheric composition outside of the CHIMERE domain may, in principle, influence the evolution of $\mathrm{NO}_{2}$ columns inside the domain, the results presented below (see Sects. 2.5 and 4.1) indicate that the effects of the long-range transport on $\mathrm{NO}_{2}$ columns can generally be disregarded. A "base" decadal run of CHIMERE was performed with the EMEP emission data for the year 2001, while the annual EMEP data were used for "control" runs. Only the results of the base run are used in the inversion algorithm. Additional control runs were performed with emission estimates obtained in this study.

2.5 Initial comparison of the decadal trends in the measured and simulated $\mathrm{NO}_{2}$ columns

Figure 2a-c presents decadal trends in the measured $\mathrm{NO}_{2}$ columns in comparison with corresponding trends in the simulated $\mathrm{NO}_{2}$ columns obtained with two versions of the EMEP data. The magnitude of the trends is estimated in a standard way as a best fit to a linear regression model. The trends are given in absolute values and for convenience Fig. 2d shows magnitudes of the tropospheric $\mathrm{NO}_{2}$ columns derived form the SCIAMACHY measurements in summer 2003. Only the grid cells, for which, according to our model calculations performed with and without anthropogenic $\mathrm{NO}_{\mathrm{x}}$ emissions, the contribution of $\mathrm{NO}_{2}$ from anthropogenic sources is dominating the total tropospheric $\mathrm{NO}_{2}$ column amount, were chosen for this study. Such selection, which is used throughout this study, helps in interpretation of our results. The magnitudes of $\mathrm{NO}_{2}$ columns over remote regions are relatively small; their significant changes (i.e. above the noise) have not yet been identified.

Large negative changes in $\mathrm{NO}_{2}$ columns dominate over Western Europe (especially over Great Britain and Germany) both in measurements and simulations. Considerable differences can be seen, however, outside of Western Europe. In particular, much larger areas have positive trends in the simulations than in the measurements. In Eastern Europe, there are also considerable differences between simulations produced with different versions of the EMEP data. It is also important to note that the spatial structure of both $\mathrm{NO}_{2}$ column amounts and their changes features strong gradients (which can be clearly seen, for example, along the coast of Great Britain). This observation provides strong evidence that the long-range horizontal transport of tropospheric $\mathrm{NO}_{\mathrm{x}}$ in the summertime does not play an important role in the $\mathrm{NO}_{\mathrm{x}}$ change/trend. However, the comparison of magnitudes and spatial distributions of $\mathrm{NO}_{2}$ column amounts simulated by the model and derived from satellite measurements is beyond the scope of this paper. Note only that the model tends to underestimate the measured $\mathrm{NO}_{2}$ columns (with the average bias about $3 \times 10^{14}$ molecules $/ \mathrm{cm}^{2}$ ) but shows a rather good spatial correlation $(r=0.87)$ between the measured and modelled $\mathrm{NO}_{2}$ columns (see also Konovalov et al., 2005, 2006a, b; Blond at al., 2007). We took into account possible uncertainties in results that may arise due to the systematic differences between the measured and modelled $\mathrm{NO}_{2}$ columns as discussed in Sect 3.4.

\section{Inversion scheme}

\subsection{Preliminary remarks}

Before going into the details of our method, we would like to outline some general principles and assumptions of this study:

1. The primary objective of our analysis is to estimate the linear trends in $\mathrm{NO}_{\mathrm{x}}$ emissions. We do not assume a priori that the trend has any particular value. As there is limited information about the uncertainties in the EMEP emission data and in the measured and simulated $\mathrm{NO}_{2}$ columns, such an assumption could lead to subjectively biased estimates. In this sense, our method is strongly driven by measurements. However, the possible range of values of trends in a given grid cell is constrained.

2. Our method also yields the interannual deviations from the linear trend: the a priori for the interannual deviation from the linear trend being zero. The a posteriori estimate for the inter-annual deviation is sought as a "compromise" between the a priori estimate and the measurements following a Bayesian approach.

3. As our goal is the estimation of the long-term changes in emissions, we do not attempt to estimate the magnitudes of emissions themselves. Only emissions for summer are investigated in this study.

4. Although satellite measurements reflect changes in total (both anthropogenic and biogenic) $\mathrm{NO}_{\mathrm{x}}$ emissions, we estimate only changes in anthropogenic emissions. This is because for the regions selected, the changes in anthropogenic emissions are assumed to dominate and overwhelm any systematic changes in emissions from lightning or natural soil sources of $\mathrm{NO}_{\mathrm{x}}$. The arguments supporting such an assumption are discussed in Sect. 3.4.

5. The relationship between $\mathrm{NO}_{\mathrm{x}}$ emissions and $\mathrm{NO}_{2}$ columns is assumed to be linear. Using our model, we determine first the linear relationship between small random perturbations in $\mathrm{NO}_{\mathrm{x}}$ emissions and resulting changes in $\mathrm{NO}_{2}$ columns, and then we use this relationship to estimate actual $\mathrm{NO}_{\mathrm{x}}$ emissions changes which could be the cause of the observed changes in $\mathrm{NO}_{2}$ 
columns. This assumption should not be confused with the assumption of constant concentration of the $\mathrm{OH}$ radical or other species, because their concentrations are also allowed to change consistently in response to the perturbations of $\mathrm{NO}_{\mathrm{x}}$ emissions. As it is argued in Sects. 4.1 and 4.2, the impact of the neglected effects associated with the nonlinearities on results of our study is rather small. The effects associated with changes in emissions of other pollutants $\left(\mathrm{CO}, \mathrm{VOCs}, \mathrm{SO}_{\mathrm{x}}\right)$ are also disregarded; the related uncertainties in our results are discussed in Sect. 3.4.

6. For this study transport of $\mathrm{NO}_{\mathrm{x}}$ is taken into account over three neighboring grid cells (that is, $200-300 \mathrm{~km}$ ), and longer range transport of $\mathrm{NO}_{\mathrm{x}}$ is disregarded.

7. The uncertainties of the retrieved emission trends are estimated by means of tests described in Sect. 3.4. It should be noted, however, that some potential uncertainties cannot be quantified with sufficient accuracy. Specifically, it is hardly possible to accurately quantify any not yet identified systematic biases in the long-term changes in $\mathrm{NO}_{2}$ columns derived from satellite measurements and similarly those obtained from the model. Accepting these limitations and potential inaccuracies of both the measured and simulated data used in the study, we provide evidence (see Sect. 4.2) that our estimates provide valuable information of an adequate accuracy, at least in comparison with available alternative data, derived from "bottom up" emission inventories.

\subsection{Basic formulations and specifications}

The probabilistic Bayesian approach (see e.g., Enting, 2002), which is common for atmospheric inverse modeling studies, is applied here. Specifically, the Bayesian estimate of interannual changes in $\mathrm{NO}_{\mathrm{x}}$ emissions is retrieved by combining the available information about inter-annual changes in the measured and modelled $\mathrm{NO}_{2}$ columns with the a priori constraints on the emission changes. Assuming that uncertainties in interannual variations of $\mathrm{NO}_{2}$ columns satisfy the normal distribution, we get the following conditional probability distribution function:

$$
\begin{array}{r}
p\left(\Delta \boldsymbol{E}^{n} \mid \Delta \mathbf{C}_{o}\right) \propto \\
\exp \left(-\frac{1}{2} \sum_{i=1}^{N}\left[\left(\Delta C_{i m}^{n}\left[\boldsymbol{E}^{n}, \Delta \boldsymbol{E}^{n}\right]-\right.\right.\right. \\
\left.\left.\left.\Delta C_{i o}^{n}\right)^{2} \sigma_{c i}^{-2}\right]\right) p_{a}(\Delta \mathbf{E})
\end{array}
$$

where $\mathbf{E}$ is a matrix of $\mathrm{NO}_{\mathrm{x}}$ emission estimates for different grid cells $i$ and years $n, \mathbf{C}_{o}$ and $\mathbf{C}_{m}$ are the observed and modelled $\mathrm{NO}_{2}$ columns (the modelled $\mathrm{NO}_{2}$ columns are a function of $\mathrm{NO}_{\mathrm{x}}$ emissions), $\Delta$ is an operator of an interannual variation (e.g., $\Delta \boldsymbol{E}^{n}=\boldsymbol{E}^{n+1}-\boldsymbol{E}^{n}$ ), $\sigma_{c}$ is the standard deviation for the uncertainties in the $\mathrm{NO}_{2}$ columns, $N$ is the total number of grid cells considered, $n$ is the number of a year, and $p_{a}$ is the a priori probability distribution (specified below) for interannual changes in emissions. This distribution assumes that, in the absence of any a priori information, the most probable value of $\Delta \mathbf{C}_{m}$ would be $\Delta \mathbf{C}_{o}$. After performing a symmetric Taylor's expansion of the modelled relationship between perturbations of the $\mathrm{NO}_{2}$ columns and $\mathrm{NO}_{\mathrm{x}}$ emissions and disregarding non-linear terms, the distribution (2) can be re-written as follows:

$$
\begin{array}{r}
p\left(\Delta \boldsymbol{E}^{n} \mid \Delta \mathbf{C}_{o}\right) \propto \\
\exp \left\{-\frac{1}{2} \sum_{i=1}^{N}\left[\left(\sum_{j=1}^{N} \Delta E_{j}^{n} \frac{\partial\left(C_{m i}^{n+1}+C_{m i}^{n}\right)}{2 \partial E_{j}}||_{\mathbf{E}=\mathbf{E}_{\mathbf{0}}-}\right.\right.\right. \\
\left.\left.\left.\Delta\left(C_{i 0}^{n}-C_{i m}^{n} \mid \mathbf{E}=\mathbf{E}_{0}\right)\right)^{2} \sigma_{c i}^{-2}\right]\right\} p_{a}(\Delta \mathbf{E})
\end{array}
$$

where $\mathbf{E}_{0}$ are emissions for the base case, corresponding here to the year 2001. The idea behind this distribution is very simple: if we have some differences between inter-annual changes in $\mathrm{NO}_{2}$ columns from observations and the model with constant emissions, we assume that this difference is probably due to corresponding changes in $\mathrm{NO}_{\mathrm{x}}$ emissions. In accordance with the assumption defined above (see Sect. 3.1, item (4)), E represents only anthropogenic $\mathrm{NO}_{\mathrm{x}}$ emissions. As common in inversion methods, we are looking for the maximum likelihood a posteriori estimates of $\Delta \mathbf{E}$ that yield a maximum of $p$. In order to insure that the a posteriori estimates of emissions are always positive, we seek the solution in terms of natural logarithms of emissions, which are denoted below as $\mathbf{e}$ (that is, we replace $\mathbf{E}$ with $\exp (\mathbf{e})$ ).

As it is common in geophysical studies, we characterize the long-term changes in the considered atmospheric characteristics by the linear trend and the year-to-year variability superimposed over the trend:

$\boldsymbol{e}^{n}=\overline{\boldsymbol{e}}+(n-\bar{n}) \Delta_{t} \boldsymbol{e}+\Delta_{d} \boldsymbol{e}^{n}$

or

$\Delta \boldsymbol{e}^{n}=\Delta_{t} \boldsymbol{e}+\Delta_{d} \boldsymbol{e}^{n} \quad, n=1, M-1$.

Here (and below) the subscripts $t$ and $d$ denote a trend (independent on the year) and a deviation from the trend, respectively, and $M$ is the total number of years considered. Note that the trend defined as a linear fit for the emission logarithms corresponds to the assumption of constant relative changes of emissions from year to year. In most cases considered in this study, the difference between the linear and exponential trends in emissions is small because trends do not exceed several percent per year. Accordingly, our inversion procedure consists of two major steps.

Firstly, we estimate $\Delta_{t} \boldsymbol{e}$ by finding values of $\Delta \boldsymbol{e}^{n}$ which provide a maximum of the distribution (3) in which $\Delta\left(\mathbf{C}_{0}-\mathbf{C}_{m}\right)$ is replaced by the linear trend in the difference $\left(\mathbf{C}_{0}-\mathbf{C}_{m}\right)$; the estimates $\Delta \boldsymbol{e}^{n}$ for each pair of neighbouring years are averaged. The trend in $\left(\mathbf{C}_{0}-\mathbf{C}_{m}\right)$ is defined similar 
to the trend in emissions (see Eq. 4) and is denoted below as $\Delta_{t}\left(\mathbf{C}_{0}-\mathbf{C}_{m}\right)$. In this step we have also to define the probability distribution function for a priori emission estimates, $p_{a}$. As we do not dispose of any specific information on uncertainty in the EMEP emission data which could provide a priori error estimates for the emission trends, we put $p_{a}$ as a constant inside realistic limits $\left(l_{\min }<\Delta_{t} \boldsymbol{e}<l_{\max }\right)$ and zero outside. Such choice of $p_{a}$ reduces our task to the following minimization problem:

$$
\begin{gathered}
\Delta \boldsymbol{e}^{n}= \\
\arg \min \sum_{i=1}^{N}\left(\left.\sum_{j=1}^{N}\left(\exp \left(\Delta e_{j}^{n}\right)-1\right) \frac{\partial\left(C_{m i}^{n+1}+C_{m i}^{n}\right)}{2 \partial e_{j}}\right|_{\mathbf{e}=\mathbf{e}_{\mathbf{0}}}\right. \\
\left.-\Delta_{t}\left(C_{i 0}^{n}-\left.C_{i m}^{n}\right|_{\mathbf{e}=\mathbf{e}_{0}}\right)\right)^{2} \sigma_{c i}^{-2} \\
\Delta \boldsymbol{e}^{n} \in\left[l_{\min }, l_{\max }\right]
\end{gathered}
$$

Limits are chosen as the mini mum and maximum values of linear trends in the EMEP $\mathrm{NO}_{\mathrm{x}}$ emissions data considered on a 1 by 1 degree grid of our model. This gives values of $1_{\min }=-0.07$ and $l_{\max }=0.1$. Such procedure gives an estimate of the spatial distribution of the $\mathrm{NO}_{\mathrm{x}}$ emission trends practically independent from the corresponding distribution based on the "bottom-up" inventory, while avoiding unrealistically large magnitudes of emission trends.

Secondly, we estimate deviations from the trend, $\Delta_{d} \mathbf{e}$, that provide the maximum of the distribution (2) where $\Delta\left(\mathbf{C}_{0}-\mathbf{C}_{m}\right)$ is replaced by $\Delta_{d}\left(\mathbf{C}_{0}-\mathbf{C}_{m}\right)$ and $p_{a}$ is a Gaussian distribution for $\Delta_{d} \mathbf{e}$ with the standard deviation equal 0.14 . This value is chosen to adjust the variance of the a posteriori deviations from the trends in Great Britain to the variance calculated for the deviation from the trends in the "new" EMEP data for the same country (about 4.2\%). Note that typical magnitudes of interannual variations in our a posteriori emission estimates are determined not only by parameters of $p_{a}$, but also by values of $\sigma_{c}$. Although the choice of Great Britain is rather arbitrary, it seems reasonable taking into account that ground based measurement of $\mathrm{NO}_{\mathrm{x}}$ in this country are used for validation of our results. Note that if we were interested only in estimates of linear trends in emissions, this second stage of our algorithm would not be needed. However, as the evolution of real emissions is not necessarily linear, an attempt to estimate $\Delta_{d} \mathbf{e}$ seems justified.

Values of the standard deviation for uncertainties in the $\mathrm{NO}_{2}$ columns, $\sigma_{c}$, which are involved in our formulations (see Eqs. 2, 3, 5), are estimated from differences between simulated and observed $\mathrm{NO}_{2}$ columns. Such estimates yield an upper bound for the uncertainties. Specifically, they are estimated as a function of magnitude of the measured $\mathrm{NO}_{2}$ columns by calculating the mean square differences between the inter-annual changes of the measured and modelled $\mathrm{NO}_{2}$ columns in a "running window" (note that only the variation of $\sigma_{c}$ from one grid cell to another is of interest in Eq. (6) and not its absolute value):

$\sigma_{c i}^{2}=\frac{1}{N_{w}} \sum_{j=1}^{N_{w}}\left(\Delta C_{o}^{k(i, j)}-\Delta C_{m}^{k(i, j)}\left(\mathbf{e}_{0}\right)\right)^{2}, \quad i=1, \ldots, N(7)$

where $N_{w}$ (which here equals 100) is the number of data points in a "window" comprising grid cells having similar magnitudes of the measured $\mathrm{NO}_{2}$ columns and $j$ is the internal index of a grid cell inside the window, and $\mathbf{e}_{0}$ are the base case emissions. This approach is described in Konovalov et al. (2005). Such defined values of $\sigma_{c}$ are found to increase monotonically from about 0.25 to $2.5 \times 10^{15} \mathrm{molec} \cdot \mathrm{cm}^{-2}$ as $\mathbf{C}_{o}$ increases from about zero to $15 \times 10^{15} \mathrm{molec} \cdot \mathrm{cm}^{-2}$.

\subsection{Numerical method}

A mathematically exact solution of our inversion problem is computationally too expensive, especially taking into account the need for additional calculations and tests aimed at estimating uncertainties in the results. Approximate methods, developed in our earlier studies, have therefore been used. The original model is substituted by a set of linear statistical models describing the relationships between perturbations of the $\mathrm{NO}_{2}$ column in a grid cell $i$ with respect to perturbations in the $\mathrm{NO}_{\mathrm{x}}$ emissions in a grid cell $j$ approximately (Konovalov et al., 2006a). Such an approximation is possible because the lifetime of freshly emitted $\mathrm{NO}_{\mathrm{x}}$ is short in summer (several hours). Our method takes into account the transport of $\mathrm{NO}_{\mathrm{x}}$ on the scale of three neighbouring grid cells (that is, $200-300 \mathrm{~km}$ ). The statistical models were created by performing 100 model runs with randomly perturbed $\mathrm{NO}_{\mathrm{x}}$ emissions for each year independently. The coefficients of the statistical models provide estimates for the derivatives $\partial \mathbf{C}_{m} / \partial \boldsymbol{E}$ in Eq. (3). Once these derivatives are evaluated, the maximum of the probability distribution can be easily found by means of standard numerical methods. Here the optimal estimates of $\Delta_{t} \boldsymbol{e}$ and $\Delta_{d} \boldsymbol{e}$ for each pair of years are obtained by means of the iterative steepest descent method using zero as initial guess. Two hundred iterations (per year) are found to be sufficient to reach the maximum of the considered probability distribution, requiring only few minutes of CPU time.

\subsection{Uncertainties in results}

In this section, uncertainties associated with the inversion method, as well as uncertainties caused by random errors in the input data will be estimated. Systematic errors in input data and the model used for inversion are difficult to estimate in a quantitative way and will be discussed below qualitatively.

In principle, the uncertainties in our emission trend estimates may come from uncertainties in (i) the measured and modelled $\mathrm{NO}_{2}$ columns, (ii) the numerical method, (iii) the a priori constraints to emission changes, and (iv) the initial 
assumptions outlined in Sect. 3.1. For the first part (i) of uncertainties in $\Delta_{t} \boldsymbol{e}$, we consider, in particular, how deviations from a trend in the columns, $\Delta_{d}\left(\mathbf{C}_{0}-\mathbf{C}_{m}\right)$, can influence the estimates of $\Delta_{t} \boldsymbol{e}$. Although such deviations are not necessarily due to uncertainties, this approach allows us to estimate, at least, an upper limit of the respective uncertainties in $\Delta_{t} \boldsymbol{e}$. Technically, we performed a Monte-Carlo experiment based on the bootstrapping method (Efron and Tibshirani, 1993): each vector $\left[\Delta\left(\mathbf{C}_{0}^{n}-\mathbf{C}_{m}^{n}\right)\right]_{d}$ corresponding to some pair of years $(n, n+1)$ is attributed to another pair (e.g., $l, l+1)$, where $l$ is a random number. The experiment included 100 inversions with such randomly mixed deviations. Note that this experiment allows us to account for uncertainties caused, in particular, by irregular annual fluctuations in biogenic emissions (e.g., due to forest fires).

In addition the uncertainty arising from the relatively large spatial resolution of GOME measurements is estimated. This is achieved by using high resolution measurements, smoothing them in the longitudinal plane and then evaluating the differences between $\mathrm{NO}_{\mathrm{x}}$ emission trends produced with the original proxy data and their smoothed counterpart. These differences can be calculated either for a single grid cell or averaged over a whole country. As the proxy for the actual spatial distribution of the decadal trends in measured $\mathrm{NO}_{2}$ columns, we used the trends calculated for three years of SCIAMACHY measurements only. Trends estimated for such a short period have limited meaning, but are used to characterise the expected heterogeneity of the spatial distribution of changes in actual $\mathrm{NO}_{2}$ columns during the longer period. The smoothed (convoluted) counterpart of SCIAMACHY data were obtained in a similar way to that used in Konovalov et al. (2006a).

In an attempt to account in a simple way for uncertainties arising from systematic biases in the modelled and measured $\mathrm{NO}_{2}$ columns (due to e.g. inaccuracies in emission rates specified in the model, see the remark (3) in Sect. 3.1), we scaled the measured $\mathrm{NO}_{2}$ columns by the mean ratio of the simulated (for the base case) and measured $\mathrm{NO}_{2}$ columns in a given grid cell and repeated the inversion procedure with such modified inputs. Differences between the results obtained with the original and with the modified input data are taken as a measure of the uncertainty in our emission trend estimates.

In order to estimate uncertainties in emission trends associated with the numerical method and approximations the following procedure has been used:

1. the observed $\mathrm{NO}_{2}$ columns were substituted by columns calculated by the model with the a posteriori emissions (serving as a substitute for an exact solution),

2. the inversion was performed, and

3. the difference between the results and the "exact" solution was determined.
This test which, in particular, justifies our assumptions about the unimportance of the long-range transport and potential nonlinearities of the relationship between $\mathrm{NO}_{2}$ columns and $\mathrm{NO}_{\mathrm{x}}$ emissions (see remarks (5) and (6) in Sect. 3.1) is considered in more detail in Sect. 4.1. Contributions from all different sources of uncertainties discussed above are summed up quadratically to provide a rough estimate of overall uncertainty in the $\mathrm{NO}_{\mathrm{x}}$ emission trend for a given grid cell or country. Note that the importance of different sources of uncertainties differs for different grid cells, regions and countries. We present below only estimates of total uncertainties and do not discuss the relative contributions of different sources in detail, particularly because our uncertainty analysis is anyway very simplistic.

Next, we discuss in a qualitative manner the impact of several systematic error sources. The a priori constraints chosen in this study can cause a bias in an estimated trend only if the actual emission trend is smaller than 7 percent and larger than 10 percent per year. However, it seems very unlikely that $\mathrm{NO}_{\mathrm{x}}$ emissions can change so rapidly in many regions. On the other hand, these constraints allow us to avoid unrealistic estimates of trends in the regions where the anthropogenic emissions are small and uncertainties in the inverted emissions are large. Therefore, we presume that, on the whole, no significant uncertainty is associated with the a priori constraint.

Uncertainties in our estimates of the trends in anthropogenic emissions may also be introduced by unaccounted for trends in biogenic emissions. However, available data (e.g. FAO, 2004; EFMA, 2005) indicate that changes in the consumption of nitrogen fertilizers in Western, Central and Eastern Europe during the considered period were rather small (less or about 5 percent). It seems reasonable to assume then that emissions from other sources of biogenic nitrogen (such as organic fertilizers and forest fires) also did not manifest significant regular changes during the last decade. Then the bias in our estimates of the trends in anthropogenic emissions caused by changes in biogenic emissions should be, on a country- wise average, well below one percent per year. For information, Table 1 provides the mean rates of anthropogenic and biogenic $\mathrm{NO}_{\mathrm{x}}$ emissions for several countries as specified in our model. For particular grid cells, trends in biogenic $\mathrm{NO}_{\mathrm{x}}$ emissions still may be larger than the average ones.

Another potential source of uncertainty in our estimates is associated with systematic uncertainties in the trends in the measured and modelled $\mathrm{NO}_{2}$ columns. As the instruments are measuring absorption of $\mathrm{NO}_{2}$, at least to a first order the ageing of instrument should not introduce an error. However, strong reduction of transmission of the instruments would result in larger noise in more recent years which has not been observed. On the whole, the GOME and SCIAMACHY measurements agree well for the period of overlap from August 2002 and June 2003 as shown by Richter et al. (2005). Nevertheless, some second order impacts of ageing may be present 
in the data set. The systematic shifts in the retrievals from satellite data may result from unaccounted changes in aerosol properties, in surface and cloud albedo and in vertical distribution of $\mathrm{NO}_{2}$. According to Richter et al. (2005) these possibilities may account only for a small fraction of the observed trends. Some biases in the trends produced by the model may be caused by global tendencies (such as changes in the composition of the stratosphere and in stratospheretroposphere exchange), which may be partly responsible for not accounted for trends in the atmospheric lifetime of $\mathrm{NO}_{\mathrm{x}}$. Within the domain of our study, the major $\mathrm{NO}_{\mathrm{x}}$ loss pathway is reaction with $\mathrm{OH}$ in the continental boundary layer. Continental boundary layer $\mathrm{OH}$ is influenced by many factors including ozone, water vapor, $\mathrm{UV}$ radiation, $\mathrm{NO}_{\mathrm{x}}$, VOC and $\mathrm{CO}$ levels. Among these factors, only trends in VOC and $\mathrm{CO}$ emissions are of the same order as the estimated trends in $\mathrm{NO}_{\mathrm{x}}$ emissions. In order to check the impact of an unaccounted trend in VOC emissions on the derived trend in $\mathrm{NO}_{\mathrm{x}}$ emissions, we performed the following test: simulations were performed with VOC emissions specified on the EMEP annual data rather than with constant VOC emissions (as in the base case). This test yielded very similar results for derived $\mathrm{NO}_{\mathrm{x}}$ emissions trends. Thus the impact in factors influencing $\mathrm{OH}$ on estimated $\mathrm{NO}_{\mathrm{x}}$ emission trends is small. This is partly due to the observation time between 10:00 and 11:00 LT which leaves little time for fresh emissions of $\mathrm{NO}_{\mathrm{x}}$ to chemically react. In conclusion and based on our current understanding of systematic uncertainties in observed or modelled $\mathrm{NO}_{2}$ columns, the associated uncertainties in our results are considered to be smaller than the statistical uncertainties estimated.

The data of the bottom-up inventory, which are compared below with the observation based emission trends, represent annual EMEP emissions processed by the standard CHIMERE interface to yield the daily average emissions for the summer season only. Seasonal factors applied to the annual data are provided for different SNAP (Selected Nomenclature for Air Pollution) sectors by IER, University of Stuttgart (GENEMIS, 1994). Differences in trends for both data sets can thus be partly due to trends in these seasonal variations. It should also be taken into account that the changes in the observed $\mathrm{NO}_{2}$ columns mainly reflect changes in the morning emissions, rather than in the 24-h average emissions. The relative fraction of different sources of $\mathrm{NO}_{\mathrm{x}}$ emissions can be dependent on whether they are considered only in the morning hours or on a twenty-four hour basis. This factor may also contribute to the differences between the $\mathrm{NO}_{\mathrm{x}}$ emission trends derived from the satellite data and those calculated using the EMEP inventory. In particular, the changes of emissions from mobile sources could contribute more strongly to the derived than to the calculated trends. In addition, the EMEP inventory does not take into account $\mathrm{NO}_{\mathrm{x}}$ emissions from aircraft. Although these emissions are relatively small on the average as compared to emissions other sources in Europe (see discussion in Konovalov
Table 1. Mean summertime anthropogenic and biogenic $\mathrm{NO}_{\mathrm{x}}$ emission rates (in $10^{10}$ molecules $\mathrm{cm}^{-2} \mathrm{~s}^{-1}$ ) for several countries, as specified in CHIMERE CTM. The anthropogenic emissions correspond to the year 2001; the biogenic emissions do not change from year to year in the model. In accordance to a general selection criterion applied in this study (see Sect. 2.5), only those grid cells are counted, for which, according to CHIMERE calculations, the contribution of $\mathrm{NO}_{2}$ from anthropogenic sources is dominating the total tropospheric $\mathrm{NO}_{2}$ column amount.

\begin{tabular}{lrr}
\hline \multicolumn{3}{c}{ Emission rates } \\
Country & Anthropogenic & Biogenic \\
\hline France & 8.9 & 4.2 \\
Former Yugoslavia & 5.4 & 1.8 \\
Germany & 20.0 & 5.7 \\
Great Britain & 18.0 & 1.0 \\
Greece & 5.6 & 1.2 \\
Iraq & 13.1 & 2.2 \\
Italy & 11.8 & 2.0 \\
Poland & 9.3 & 2.3 \\
Russia & 5.8 & 1.3 \\
Spain & 10.8 & 1.2 \\
Turkey & 5.8 & 1.0 \\
Ukraine & 6.4 & 2.3 \\
\hline
\end{tabular}

et al., 2006a and references therein), their strong changes in some regions may also contribute to the difference between our estimates and EMEP data.

\section{Results}

\subsection{Decadal trends in $\mathrm{NO}_{\mathrm{x}}$ emissions}

Figure 3 presents our estimates of $\mathrm{NO}_{\mathrm{x}}$ emission trends in comparison with corresponding trends in anthropogenic emissions specified in the CHIMERE CTM for the summer time. The white dots on Fig. 3a mark grid cells for which the difference between the emission trends found in our study and calculated with the latest EMEP data is statistically significant (in terms of $1 \sigma$ roughly estimated as discussed in Sect. 3.4). It is evident that both the similarities and differences between our estimates and the expert data are numerous. Among the similarities are predominantly negative trends over Western and Central Europe. This includes countries such as Austria, Belgium, Bulgaria, the Czech Republic, France, Germany, Great Britain, the Netherlands, Poland, Slovakia and Switzerland. In contrast, positive trends are derived over ship tracks in the Mediterranean Sea and along the coast of Portugal both by our inversion method and by EMEP. These results are important, because they allow a direct confirmation of the estimation of emission trends made by EMEP with satellite based measurements. 

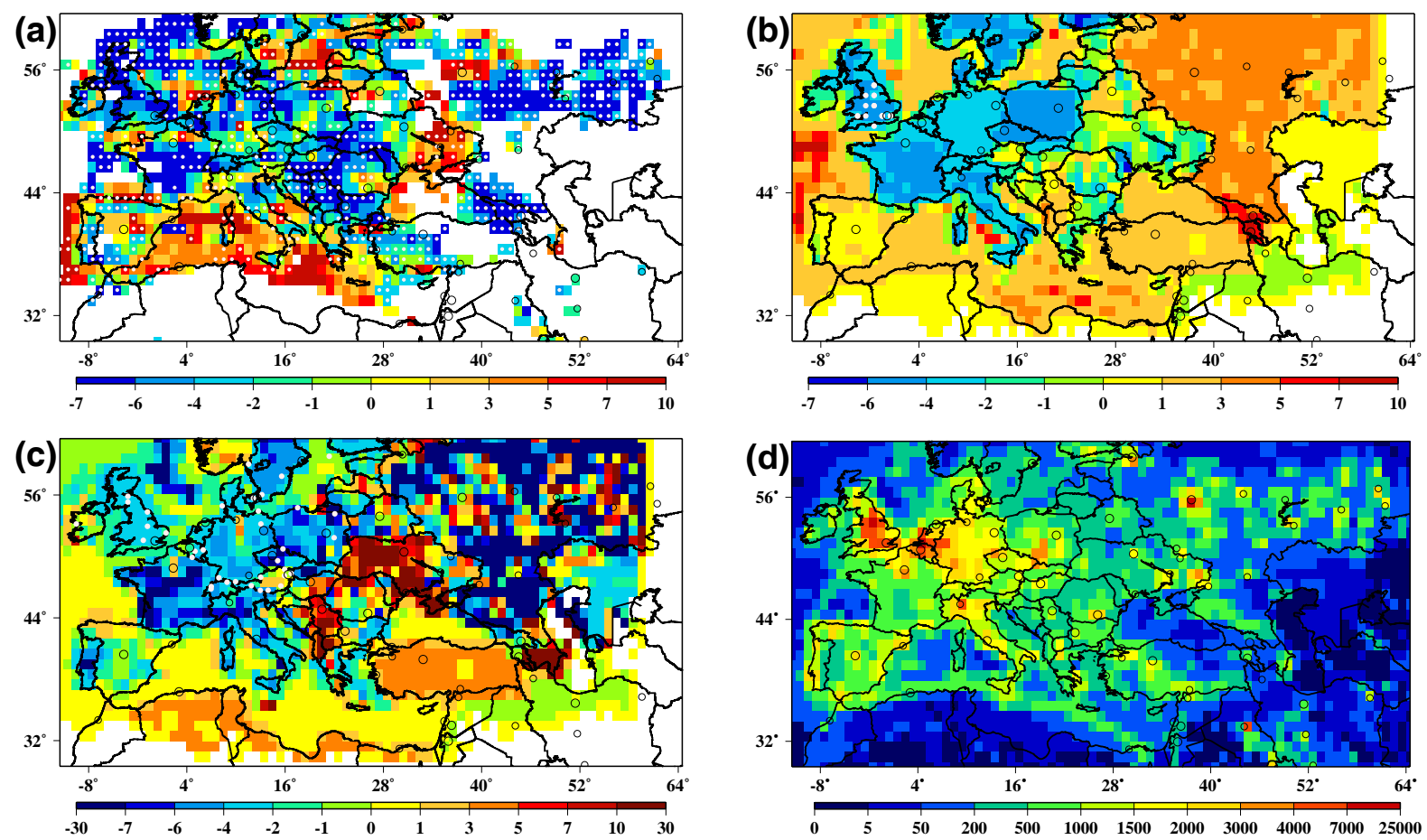

Fig. 3. Decadal trends (percent per yr) in summertime anthropogenic $\mathrm{NO}_{\mathrm{x}}$ emissions (a) estimated in this study and calculated with (b) the most recent and (c) older EMEP data along with (d) magnitudes of the summertime anthropogenic $\mathrm{NO}_{\mathrm{x}}$ emission rates prescribed in CHIMERE for the year 2001 (in molecules $\times \mathrm{cm}^{-2} \times \mathrm{s}^{-1} \times 10^{8}$ ). Blank dots mark (a) grid cells for which the difference between the emission trends is significant in terms of $1 \sigma$, (b) grid cells (in UK) for which near surface $\mathrm{NO}_{\mathrm{x}}$ measurements are available, and (c) locations of EMEP sites selected for the study.

Large differences are seen, in particular, in Balkan countries, Georgia, Russia and Turkey, where our analysis yields predominantly negative trends in contrast to positive trends obtained with the expert data. It is especially interesting to note that the measurement based trends feature larger spatial heterogeneity than the new EMEP data. In particular, there is a clear evidence of positive trends in the regions around the largest Russian cities such as Moscow, St. Petersburg and Nizhniy Novgorod, while the rest of Russia shows predominantly negative trends. Strong positive trends are also found in industrial regions of the Eastern Ukraine, while the Western Ukraine manifests mostly negative trends. These results are pinpointing particular regions where the EMEP trend estimates could have problems for whatever the reason.

Figures 4 and 5 present the time series of $\mathrm{NO}_{\mathrm{x}}$ emissions averaged over several countries. Rather close agreement between the new EMEP data and our estimates is found for France, Germany, Great Britain and Spain. Statistically significant differences between our results and the expert estimates are found for Italy, where our data suggest that the decrease in $\mathrm{NO}_{\mathrm{x}}$ emissions in the EMEP inventory is strongly overestimated. In Greece, the expert data show rather irregular behavior, and our estimates are also rather uncertain. It is interesting to note that our estimates of the trends are in better agreement with new EMEP emission data than with old ones for all countries shown in Fig. 4. It is further interesting, that for several Mediterranean countries (Greece, Italy and Spain), neutral or positive trends are predicted from satellite data, contrary to the negative trends for Western and Central European countries.

The differences between our results and the expert emission data are larger outside of Western Europe. In particular, the directions of the trends in the measurement-based and the new EMEP data differ in Turkey, Ukraine, Russia and Former Yugoslavia. The differences between the old and new EMEP data are relatively large here, especially for Ukraine and Russia. For these countries, the new EMEP emissions do not compare better with our estimates than the old ones. These observations indicate that the current knowledge about emissions and their inter-annual changes in former USSR countries, in the Balkans and in the Middle East is still very incomplete and probably inadequate.

As a result of large uncertainties in the input data, the yearto-year variations superimposed on the trend could not be estimated sufficiently accurately. Probably, such variability in our data mostly reflects uncertainties in the model and 

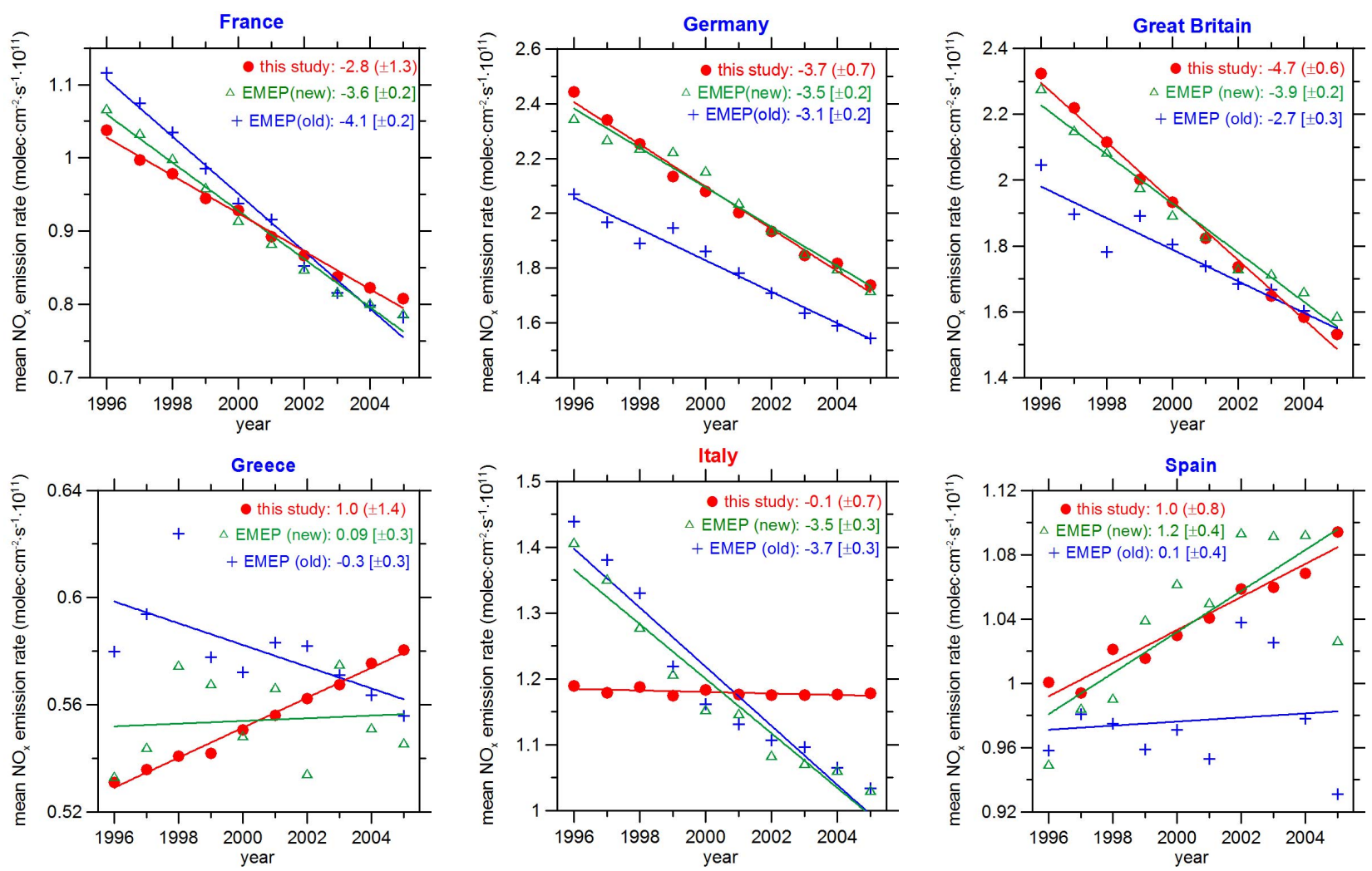

Fig. 4. The time series and linear trends in anthropogenic $\mathrm{NO}_{\mathrm{x}}$ emissions averaged over several countries. Values provided in round brackets are estimates of uncertainties (see Sect. 3.4). Values reported in square brackets are the statistical uncertainty (the standard deviation) of a linear fit to the EMEP data (not including systematic uncertainty).

measurements, but in some cases (e.g., in Russia between 1998 and 1999 and in Iraq between 2002 and 2003), it may also be due to actual emission changes. The deviations from the trends for Russia and Iraq are zoomed and shown by pink lines in Fig. 5. A stronger, than on the average, decrease of $\mathrm{NO}_{\mathrm{x}}$ emissions in Russia in 1999 could be attributed to consequences of a severe economic crisis which happened in August of the previous year. The magnitudes of these variations are probably strongly underestimated as a result of the uncertainties in input data and a priory constraint on the interannual variability of emissions (see Sect. 3.2). In other words, whenever the information on actual change in emissions is insufficient, our method yields a near-zero deviation from a linear trend as the best solution. We checked that when the a priori constraint on the interannual variability of emissions is relaxed, our estimates become more uncertain as indicated by results of their validation by ground based measurements. Note that the uncertainties and corresponding variations in emission estimates which have a quasi-random character for individual grid cells tend to be mutually compensated when our estimates are averaged over the whole country.

Figure 6 presents results of the special test which was described earlier (see Sect. 3.4). The emission trends shown are derived from $\mathrm{NO}_{2}$ columns calculated with our estimates of inter-annual changes of $\mathrm{NO}_{\mathrm{x}}$ emissions and can be compared with the emission trends shown in Fig. 3a. The agreement between Figs. 3a and 6 would be perfect if (1) the inversion scheme was perfect, (2) the input data (the $\mathrm{NO}_{2}$ columns from the measurements and simulations) did not contain any uncertainties, and (3) there were no a priori constrains to the estimates of the emission trends. As neither of these conditions is satisfied exactly, the agreement is not ideal, but still it is obvious that the spatial distributions of the emissions trends shown in Figs. $3 a$ and 6 are very similar. This similarity indicates that our scheme works properly and the approximations made are legitimate.

The differences between estimates of emission trends retrieved in this study and those from EMEP may yet be explained by unidentified systematic errors in either of the approaches (see discussion in Sect. 3.4). However, the rather good agreement of our trend estimates with the EMEP data in the regions where the bottom-up inventories are likely to be most accurate lends confidence to satellite derived trends in regions where larger differences with the EMEP trends appear.We hope that our results will give rise to further studies aimed at clarifying the reasons for the disagreement between the "top-down" and "bottom-up" inventories. 

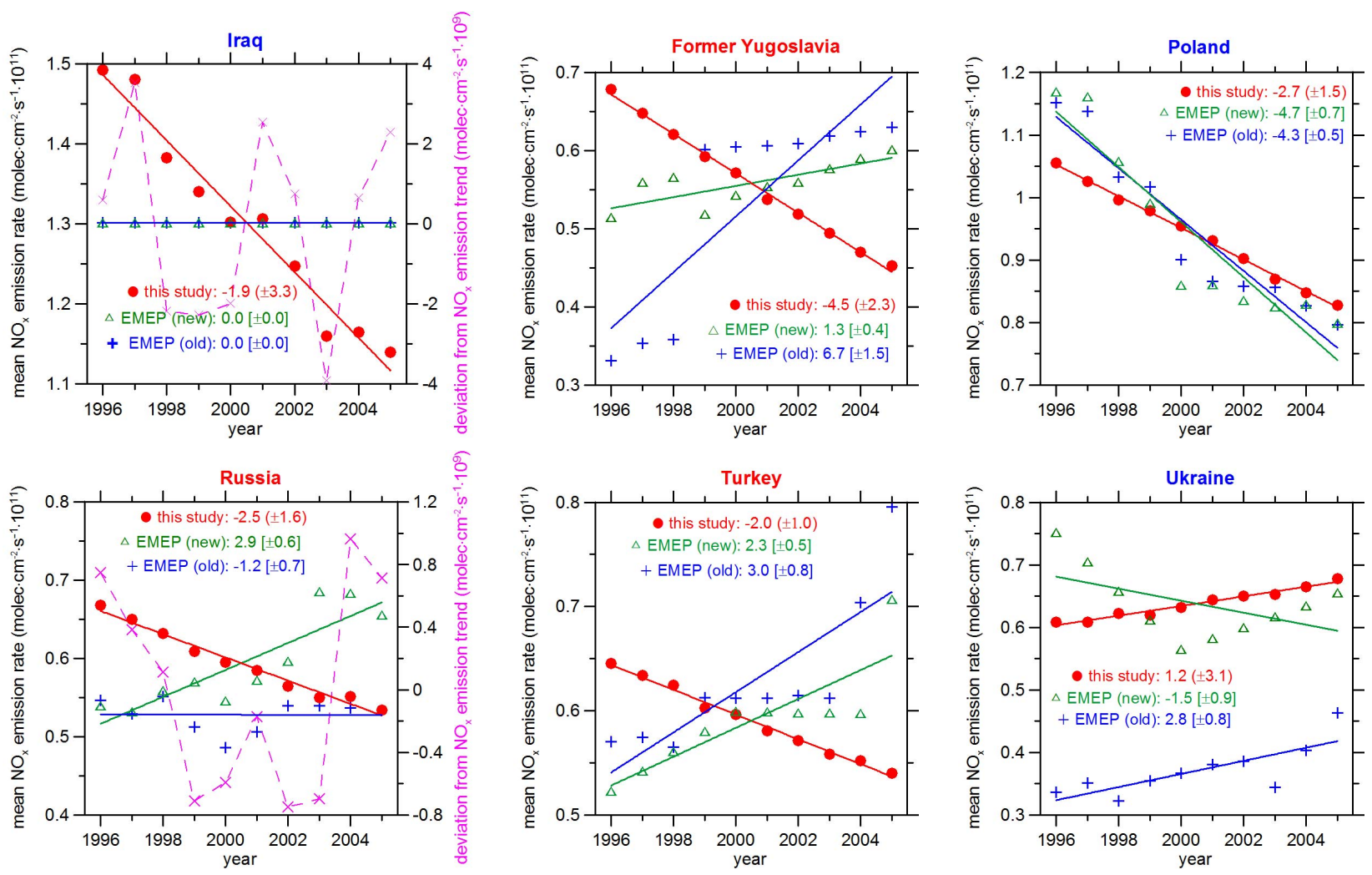

Fig. 5. The same as in Fig. 4, but for other countries. Additionally, the pink dashed lines show deviations from the measurement-based emission trends for Iraq and Russia.

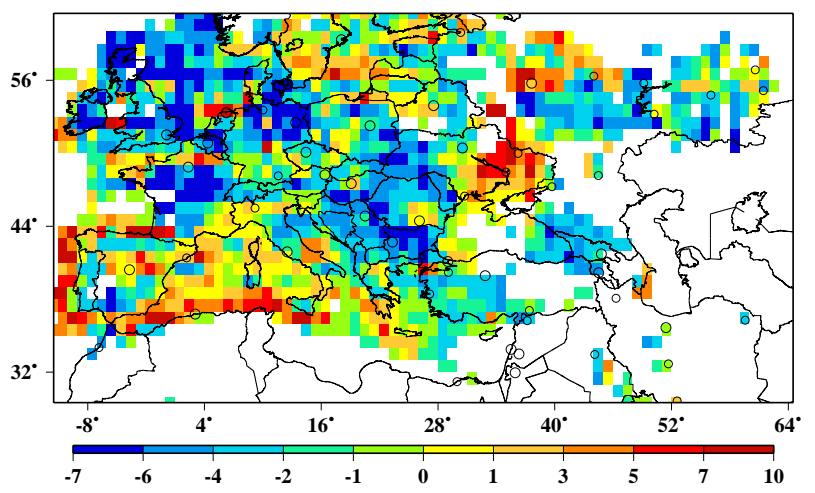

Fig. 6. The $\mathrm{NO}_{\mathrm{x}}$ emission trends (in percent per yr) derived from $\mathrm{NO}_{2}$ columns that were calculated with our estimates of interannual changes of $\mathrm{NO}_{\mathrm{x}}$ emissions. These trends can be compared with the original $\mathrm{NO}_{\mathrm{x}}$ emission trends shown in Fig. 3a. The agreement is not expected to be perfect due to uncertainties in input data and a priori constraints, but the evident similarity of the results shown in this figure and Fig. 3a indicates that our inversion scheme operates properly.
4.2 Checking the agreement between the measurement data and simulations obtained with the measurement-based emission estimates

The optimization of $\mathrm{NO}_{\mathrm{x}}$ emissions should lead to improvements in the agreement between the modelled and measured data. The comparison between trends in $\mathrm{NO}_{2}$ columns derived from satellite measurements and trends calculated with the optimised $\mathrm{NO}_{\mathrm{x}}$ emissions is presented in Figs. 7 and 8 for the same countries that were considered earlier (see Figs. 3 and 4). The trends in $\mathrm{NO}_{2}$ columns calculated with the "new" EMEP emissions are also shown in Figs. 7 and 8. In order to facilitate the comparison of the trends, the modelled time series have been preliminary centred, so that they coincide with the measurements on the average, but without altering relative trends. In most cases considered, both the measured and simulated time series demonstrate strong interannual changes superimposed over linear trends. This variability may reflect changes in the meteorological situation, but it also may be due to uncertainties in the model and measurements. In some cases (e.g. in Iraq in 2003), the deviations from a trend may also be caused by strong changes in emissions. 

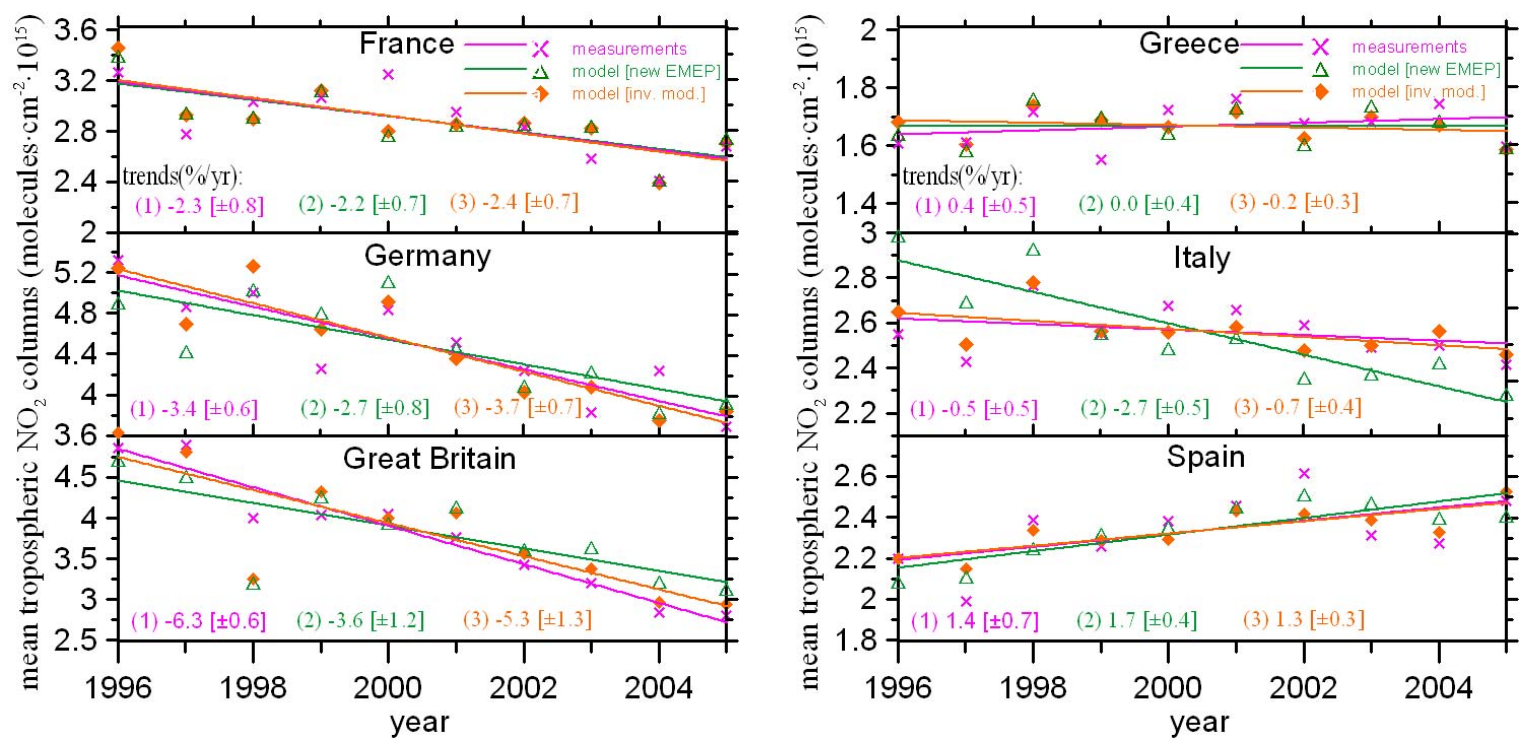

Fig. 7. The time series and linear trends (in percent per year) in the satellite measured and modelled $\mathrm{NO}_{2}$ columns averaged over several countries. The orange diamonds and lines show the results of the model run performed with emission estimates derived from satellite measurements. In order to facilitate the comparison of the trends, the modelled $\mathrm{NO}_{2}$ columns (averaged over a respective country) for each year have been multiplied by a ratio of the mean values of measured and modelled $\mathrm{NO}_{2}$ columns.

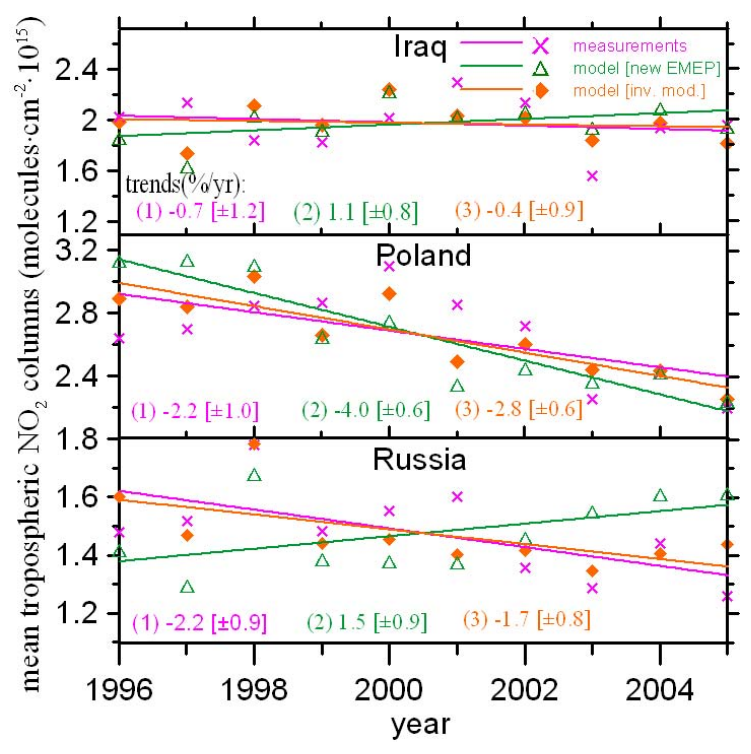

Fig. 8. The same as in Fig. 7, but for other countries.

It is easy to see that the measurement-based emission estimates yield an excellent agreement (within the uncertainty of the linear fits) between trends in the satellite data and simulations for all countries considered. This agreement is obviously better than that in case of $\mathrm{NO}_{2}$ columns calculated with the EMEP emissions. These results indicate, in particular, that the impact of neglected effects associated with nonlinearities in the dependence of $\mathrm{NO}_{2}$ columns on $\mathrm{NO}_{\mathrm{x}}$ emis-

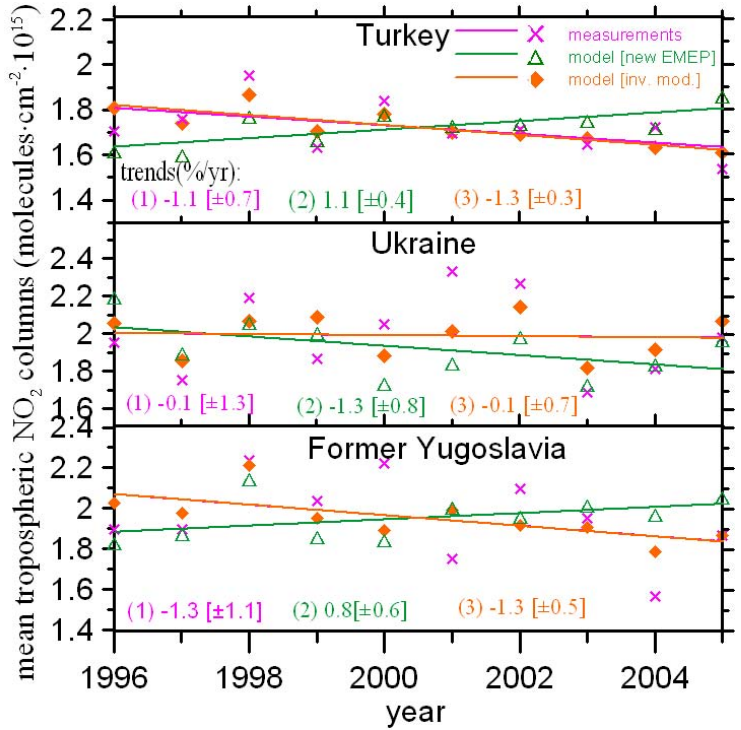

sions and the long-range transport of $\mathrm{NO}_{\mathrm{x}}$ on our estimates of $\mathrm{NO}_{\mathrm{x}}$ emission changes is indeed rather small. It is interesting to note that for many countries (but not for all), the trends in the measured $\mathrm{NO}_{2}$ columns and the derived $\mathrm{NO}_{\mathrm{x}}$ emissions are rather similar. From the theoretical point of view, trends in $\mathrm{NO}_{2}$ columns and in anthropogenic $\mathrm{NO}_{\mathrm{x}}$ emissions can indeed be similar but should not be exactly the same, except for the special case when the transboundary transport is 


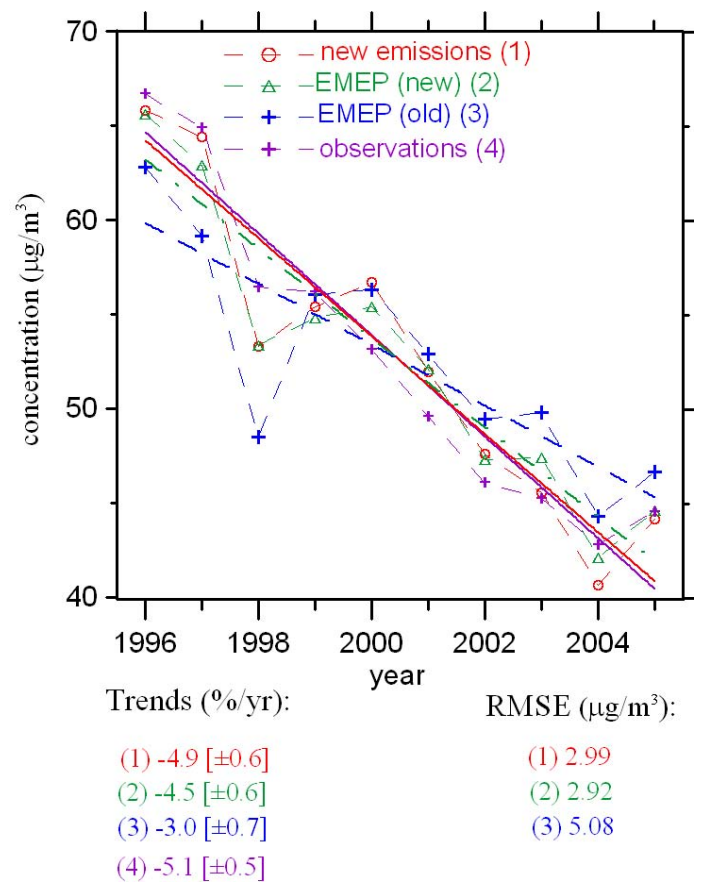

Fig. 9. Comparison of $\mathrm{NO}_{\mathrm{x}}$ results of a model run for which changes of $\mathrm{NO}_{\mathrm{x}}$ emissions were specified using either (1) results of this study or (2) the most recent and (3) older expert data of the EMEP inventory with (4) measurement data for $\mathrm{NO}_{\mathrm{x}}$ near surface concentrations at AURN in Great Britain. The measurement and modelled data from individual monitors were combined to equalise contributions from sites with different level of air pollution (see Sect. 4.2 for details). One sigma uncertainties in trends are indicated in brackets.

negligible, the horizontal mixing is homogeneous, the lifetime of $\mathrm{NO}_{\mathrm{x}}$ is the same everywhere, and the contribution from other sources of $\mathrm{NO}_{\mathrm{x}}$ is also negligible. An in-depth analysis of these similarities and differences goes beyond the scope of this study.

Of course, the improvement in the agreement between the measured and modelled $\mathrm{NO}_{2}$ columns can only be considered as necessary but still insufficient evidence that our emission estimates are sufficiently accurate. The comparison with independent data such as near surface ozone and $\mathrm{NO}_{\mathrm{x}}$ concentrations provides a much more critical test of our results.

The locations of the ground-based monitors that we considered in this study are marked by blank dots in Fig. 3b, c. Specifically, Fig. $3 b$ shows the coordinates of the UK AURN monitoring stations, and Fig. 3c indicates locations of EMEP monitors. Unfortunately, the ground-based measurements are available only for areas where the differences between our estimates and the EMEP data are not so large. Note also that the UK stations tend to be clustered within and around major cities. In particular, 7 stations out of 21 considered are located in London and its nearest suburbs; these stations correspond to only two grid cells of our model. The results

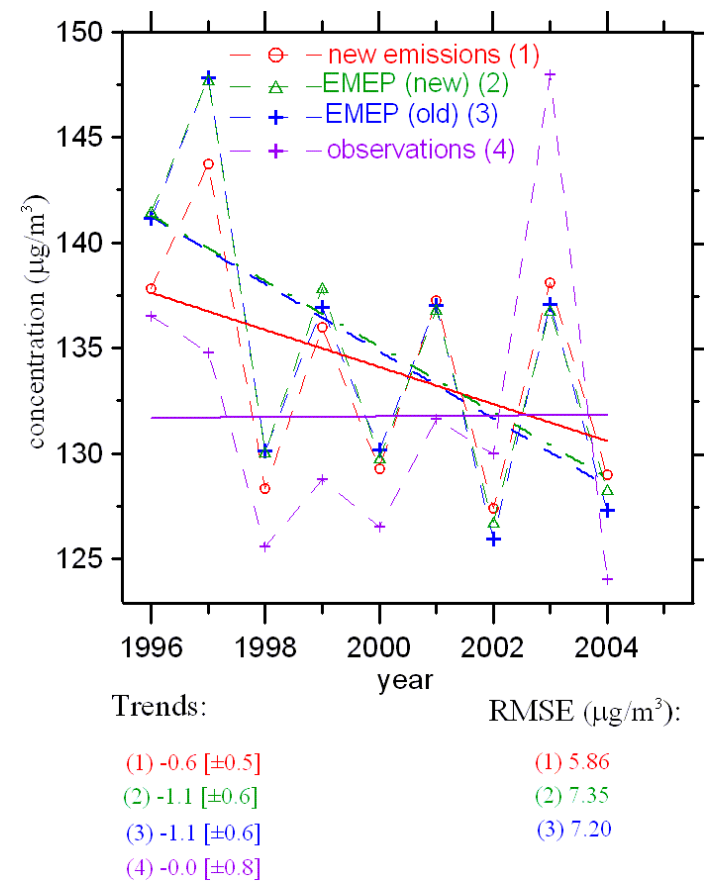

Fig. 10. Comparison of $\mathrm{O}_{3}$ results of a model run for which changes of $\mathrm{NO}_{\mathrm{x}}$, VOC and $\mathrm{CO}$ emissions were specified using either (1) results of this study or (2) the most recent and (3) older expert data of the EMEP inventory with (4) measurement data for ozone concentrations from the EMEP monitoring network. The time series shown represent 90 percentile of measurement data and their counterparts averaged over all 36 EMEP sites selected for this study. One sigma uncertainties in trends are indicated in brackets.

of comparison of the ground-based measurements with corresponding model results are summarized in Figs. 9 and 10.

While performing simulations of near surface concentrations of ozone and $\mathrm{NO}_{\mathrm{x}}$ with our estimates of $\mathrm{NO}_{\mathrm{x}}$ emissions, we used two different options regarding $\mathrm{CO}$ and VOC emissions. The first option was to assume that the relative interannual changes of emission of $\mathrm{CO}$ and hydrocarbons are the same as those of $\mathrm{NO}_{\mathrm{x}}$ emissions. Indeed, $\mathrm{VOC}$ and $\mathrm{NO}_{\mathrm{x}}$, as well as CO have many common sources, and thus the multiannual changes of their emissions likely covariate to some extent. Another option was to use the annual EMEP data for emissions of $\mathrm{CO}$ and VOC, but we kept in mind that their uncertainty is probably as large as the uncertainty in the expert data for $\mathrm{NO}_{\mathrm{x}}$ emissions. When it is not specified otherwise, the results are reported for the first (main) option. The second option is discussed below only in the case of ozone simulations, since the results for $\mathrm{NO}_{2}$ columns and $\mathrm{NO}_{\mathrm{x}}$ near surface concentrations obtained with the expert annual data for VOC and $\mathrm{CO}$ emissions do not differ significantly from the respective results obtained with the first option.

In case of $\mathrm{NO}_{\mathrm{x}}$ measurements (Fig. 9), we considered a combined time series in which measurement data from different monitors and simulated data for the monitoring sites 
are weighed in order to equalize contributions from sites with very different level of air pollution. The weights have been defined such that the seasonally-mean $\mathrm{NO}_{\mathrm{x}}$ concentrations averaged over 10 years at each of the sites is equal after weighing to the total average (both over years and sites) of the seasonally-mean measured $\mathrm{NO}_{\mathrm{x}}$ concentrations before weighing. It is useful to note that direct comparison of the $\mathrm{NO}_{\mathrm{x}}$ measurements and model calculations performed with 1-degree resolution would hardly make any sense because of the large representativeness errors which, nevertheless, are expected to be less important when the goal is to compare relative inter-annual changes in simulated and measured $\mathrm{NO}_{\mathrm{x}}$ concentrations.

It can be seen that clear improvements both in the trends and RMSE (defined as the RMS difference between respective time series) calculated for $\mathrm{NO}_{\mathrm{x}}$ concentrations take place when the old EMEP data are replaced either with new expert data or our own estimates. In particular the use of our $\mathrm{NO}_{\mathrm{x}}$ emission estimates reduces RMSE from 5.1 to $3.0 \mu \mathrm{g} / \mathrm{m}^{3}$ and reduces the difference between the time series for $9 \mathrm{yr}$ (considered individually) out of 10 . The binomial statistics indicates that the hypothesis that such changes are entirely random must be rejected with high confidence (about 98 percent). The difference between results obtained with our emission estimates and new EMEP data is very small and statistically insignificant: the RMSE calculated with our emission estimates $\left(3.0 \mu \mathrm{g} / \mathrm{m}^{3}\right)$ is slightly larger than that obtained with the new EMEP data $\left(2.9 \mu \mathrm{g} / \mathrm{m}^{3}\right)$, the trend in simulated data gets slightly closer to the trend in the measurement data, and the improvements in agreement between the data for individual years take place only for $6 \mathrm{yr}$. These results indicate that the new EMEP data for Great Britain are already rather good.

Note that chemiluminescence analyzers which are employed in the UK automatic network may overestimate the actual concentration of $\mathrm{NO}_{2}$ because of interference of non$\mathrm{NO}_{\mathrm{x}}$ reactive nitrogen $\left(\mathrm{NO}_{\mathrm{z}}\right)$ species. For example, Dunlea et al. (2007) found that, during the MCMA-2003 field campaign in Mexico City (April 2003), the interference of $\mathrm{NO}_{\mathrm{z}}$ species resulted in average $\mathrm{NO}_{2}$ concentrations measured by the chemiluminescence monitors up to 22 percent greater than that from co-located spectroscopic measurements. Steinbacher et al. (2007) found that, on the average, only 70-83 percent of $\mathrm{NO}_{2}$ measured at a non-elevated rural site could be attributed to real $\mathrm{NO}_{2}$. We have no specific information about possible artifacts in the considered $\mathrm{NO}_{\mathrm{x}}$ measurement in Great Britain, but it seems probable that they should be much smaller than those mentioned above. Indeed, the majority of the selected $\mathrm{NO}_{\mathrm{x}}$ monitors (19 out of 21) are located in urban areas, and, therefore, the ratio of concentrations of secondary pollutants containing nitrogen (such as $\mathrm{HNO}_{3}$ and alkyl nitrates) to those of primary $\mathrm{NO}_{\mathrm{x}}$ pollutants at the selected AURN sites should be significantly smaller than at the rural sites considered by Steinbacher et al. Similarly, the climate in Mexico City is warmer and actinic fluxes larger than in Great Britain, and thus it is more favorable to oxidation processes. A bias which these artifacts may cause in the measured negative trend in $\mathrm{NO}_{\mathrm{x}}$ concentrations in UK is likely positive, because concentrations of $\mathrm{OH}$ and $\mathrm{O}_{3}$, which are responsible for the oxidation of $\mathrm{NO}_{\mathrm{x}}$ species, are likely to increase in urban sites as $\mathrm{NO}_{\mathrm{x}}$ emissions decrease. The magnitude of this bias is quite difficult to assess; most probably, it is less than 10 percent of the measured trend. Such bias cannot change any conclusions of this study.

Tropospheric $\mathrm{O}_{3}$ is exhibiting two diametrically opposed behaviors being observed world wide, the peak $\mathrm{O}_{3}$ values in urban areas of EU and US has been coming down (especially during the 1990s) as a result of regulation, but the background is continuing to increase. For the ground based ozone in this study (see Fig. 10), we compared the average (over all EMEP sites considered) of 90 percentiles (defined for each monitoring site during the considered summer seasons) of measured daily maxima of ozone concentrations with the average of daily maxima of simulated ozone concentrations sampled on the same days when the respective 90 percentile in the measured concentration was observed. It can be seen that the observed trend is near zero, while all model calculations show small negative trends. The difference between the observed and modelled trends is not statistically significant and, most probably, it should be attributed to "random" uncertainties in the model (caused, e.g., by imprecision of meteorological data and chemical scheme). Our results do not allow us to completely exclude the role of some more "systematic" reasons for differences in the trends such as positive trends in boundary conditions (Simmonds et al., 2005; Ordonez et al., 2007) or changes in reactivity of hydrocarbons. But still, the improvements which take place with our emissions are rather considerable both in the trend and in RMSE. In particular, RMSE (defined for the time series shown in Fig. 10) is reduced by 20 percent (from 7.4 to $5.9 \mu \mathrm{g} / \mathrm{m}^{3}$ ) in comparison with the simulation based on the new EMEP emissions. The improvements in RMSE take place for the majority (27 out of 36) of sites and 7 (out of 9) annual data points (see Fig. 10) considered independently. The binomial statistical test indicates that the "null" hypothesis ("the changes are completely random") applied to the statistical ensembles of individual monitors or individual years should be rejected with the probabilities of 99.6 in the case of sites and 82 percents in the case of annual data. The improvements are distributed rather homogeneously across regions where the long-term measurements took place. Specifically, the numbers of sites, for which RMSE was reduced, versus the total numbers of sites in different countries are as follows: 5/9 in Austria, 2/2 in Belgium, 2/3 in Switzerland, 1/1 in Czechia, 3/4 in Germany, 1/1 in Denmark, 0/1 in Finland, 1/1 in France, 6/6 in Great Britain, 0/1 in Ireland, 1/1 in Norway, 3/4 in Poland, and 2/2 in Sweden.

Some (smaller) improvements are found when the changes of VOC and CO emissions were specified using the EMEP data. In this case, the RMSE is reduced by about 4 percent 
(from 7.4 to $7.1 \mu \mathrm{g} / \mathrm{m}^{3}$ ), the improvements in RMSE are found in 22 individual sites (with the probability that the "null" hypothesis is wrong to be 76 percent), the magnitude of the trend remained the practically same.

In conclusion, our estimates of $\mathrm{NO}_{\mathrm{x}}$ emission changes are consistent (within the range of uncertainties caused by other factors) with measurement data both for tropospheric $\mathrm{NO}_{2}$ column amounts and near-surface concentrations of ozone. Although we cannot claim that our estimates are more precise than the emission data based on the EMEP inventory everywhere, our analysis has shown that they are at least not worse on the whole. Our estimates may yield largest improvements in simulation of near surface concentrations in the regions where the directions of the trends in the topdown and bottom-up estimates of $\mathrm{NO}_{\mathrm{x}}$ emissions are opposite (e.g. in Russia and Turkey), but unfortunately no measurements are available there. The disagreement between different emission data can be considered as evidence that the knowledge of emissions in these regions is currently inadequate.

\section{Conclusions}

In this study we used the data on tropospheric $\mathrm{NO}_{2}$ columns amounts derived from long-term satellite measurements of GOME and SCIAMACHY in order to investigate and estimate decadal changes (between 1996 and 2005) in $\mathrm{NO}_{\mathrm{x}}$ emissions in Europe, the Mediterranean and the Middle East. To this end, the measurement data were combined in the framework of an original inverse modelling scheme with calculations performed with a continental scale CTM. In contrast to more common approaches, our algorithm does not rely on a priori estimates of the inferred quantities and does not require explicit assumptions about the magnitudes of uncertainties in emission inventories, measurement data and model results. We constrain a priori only maximum magnitudes of the emission trends and inter-annual variations superimposed on the trend. Results obtained with this method are highly relevant, because they allow confirmation and improvement of "expert" emissions trends by means of independent information. In contrast to surface measurements, satellite measurements have the necessary spatial coverage needed for such a study and can be extended to other regions lacking high quality monitoring networks.

Our results indicate that, in agreement with expert estimates, $\mathrm{NO}_{\mathrm{x}}$ emissions in Europe have been generally decreasing (with some exceptions) in Western and Central Europe. Stronger decreases are calculated for Great Britain, Germany and France, where we found the trends in $\mathrm{NO}_{\mathrm{x}}$ emissions to be $-4.7 \pm 0.6,-3.7 \pm 0.7$, and $-2.8 \pm 1.3$ percent per year, respectively. These results are also in qualitative agreement with independent studies (Jonson et al., 2006; Vautard et al., 2006), which conclude that $\mathrm{NO}_{\mathrm{x}}$ and VOC emission reductions are not in contradiction with ob- served surface ozone (higher percentiles) over Western Europe in the nineties. Rather stable emissions are calculated for Mediterranean countries (Spain, Italy, Greece), and increasing emissions on Atlantic and Mediterranean ship tracks. Significant decreasing trends are also found for some of the biggest Eastern European and Middle East countries such as Poland $(-2.7 \pm 1.5)$, Russia $(-2.5 \pm 1.6)$ and Turkey $(-2.0 \pm 1.0)$. In Russia, the spatial structure of the measurement based trends demonstrates strong heterogeneity, with positive trends concentrating around the largest Russian megacities such as Moscow, St.-Petersburg and Nizhny Novgorod. Strong heterogeneity in the distribution of $\mathrm{NO}_{\mathrm{x}}$ emissions trends is also found in Ukraine, where the eastern industrial regions show strong positive trends, whereas negative trends are dominating in western regions.

Our "top-down" estimates of emission trends were compared with trends calculated with "bottom-up" emission data based on the most recent EMEP inventory. The differences between the trends calculated with these two kinds of data are found to be within the range of uncertainties for most of the countries considered, but there are also several exceptions. In particular, our estimates suggest that the negative trend is much smaller than predicted by the experts in Italy. Negative trends instead of positive ones in the expert data are found for Balkan countries, Russia and Turkey. Additionally, we compared our results with those calculated using $\mathrm{NO}_{\mathrm{x}}$ emissions from an older version of the EMEP data (obtained from the EMEP website before 1 December 2006). We found that our estimates better agree with the more recent EMEP data than with older ones for the biggest Western European countries, as well as Greece, Former Yugoslavia and Turkey, but no improvements are found for Russia and Ukraine.

Model runs using the obtained estimates of emission changes were found to demonstrate a satisfactory agreement with data of independent near-surface measurements of $\mathrm{NO}_{\mathrm{x}}$ in Great Britain and ozone at stations of the European EMEP network. In case of $\mathrm{NO}_{\mathrm{x}}$, we found the simulations performed with our estimates to be more consistent with the measurements than the simulations performed with the older version of the EMEP data (obtained before 1 December 2006), while no significant difference is found between simulations performed with the measurement-based and more recent EMEP emissions. In case of ozone, statistically significant improvements of the agreement between simulations and measurements are found when the simulations are performed with our emission estimates in comparison with simulations produced with both versions of the EMEP data. The demonstration of greater potential of our estimates in improving simulations of near surface concentrations is hampered by the fact that the long-term ground based measurements are available mostly for regions where the difference between "top-down" and "bottom-up" estimates of $\mathrm{NO}_{\mathrm{x}}$ emissions trends is relatively small. Data from different national monitoring networks in EU countries may provide more useful information for validation of emission estimates 
derived from satellite measurements. Such work can be performed in the future.

Overall, this study demonstrated that available satellite data combined with modeling results can be of great value in obtaining realistic estimates of multi-annual $\mathrm{NO}_{\mathrm{x}}$ emission changes. We believe that the long-term satellite measurements of $\mathrm{NO}_{2}$ and other species together with modern inverse modeling methods open a promising perspective for global monitoring of emission changes and provide the basis for improving quality of data of traditional emission inventories.

Acknowledgements. I. B. Konovalov acknowledges the support of Russian Foundation for Basic Research (grants No. 05-05-64365-a, 08-05-00969-a), Russian Academy of Sciences (in the framework of the Programme for Basic Research "Physics of Atmosphere; Electrical Processes, Radiophysical Methods of Research"), Centre National de la Recherche Scientifique (CNRS) and the University Paris-12. M. Beekmann acknowledges support from the French LEFE-CHAT program. SCIAMACHY raw data were provided by ESA through DFD/DLR. Analysis of the SCIAMACHY data was supported by the European Union through ACCENT and by the University of Bremen. The authors acknowledge data provided by participants of the EMEP measurement network.

Edited by: R. Cohen

\section{References}

Beirle, S., Platt, U., Glasow, R.V., Wenig, M., and Wagner T.: Estimate of nitrogen oxide emission from shipping by satellite remote sensing, Geophys. Res. Lett., 31(18), L18102, doi:10.1029/2003JD003652, 2004.

Beirle S., Spichtinger, N., Stohl, A., Cummins, K. L., Turner, T., Boccippio, D., Cooper, O. R., Wenig, M., Grzegorski, M., Platt, U., and Wagner, T.: Estimating the $\mathrm{NO}_{\mathrm{x}}$ produced by lightning from GOME and NLDN data: a case study in the Gulf of Mexico, Atmos. Chem. Phys., 6, 1075-1089, 2006,

http://www.atmos-chem-phys.net/6/1075/2006/.

Bertram, T. H., Heckel, A., Richter, A., Burrows, J. P., and Cohen, R. C.: Satellite measurements of daily variations in soil NOx emissions, Geophys. Res. Lett., 32(24), L24812, doi:10.1029/2005GL024640, 2005.

Blond N., Boersma, K. F., Eskes, H. J., van der A, R. J., Van Roozendael, M., De Smedt, I., Bergametti, G., and Vautard, R.: Intercomparison of SCIAMACHY nitrogen dioxide observations, in situ measurements and air quality modeling results over Western Europe, J. Geophys. Res., 112, D10311, doi:10.1029/2006JD007277, 2007.

Boersma, K. F., Eskes, H. J., Meijer, E. W., and Kelder, H. M.: Estimates of lightning $\mathrm{NO}_{\mathrm{x}}$ production from GOME satellite observations, Atmos. Chem. Phys., 5, 2311-2331, 2005,

http://www.atmos-chem-phys.net/5/2311/2005/.

Bousquet, P., Peylin, P., Ciais, P., Le Quere, C., Friedlingstein, P., and Tans, P. P.: Regional changes in carbon dioxide fluxes of land and oceans since 1980, Science, 290, 1342-1346, 2000.
Bovensmann, H., Burrows, J. P., Buchwitz, M., et al.: SCIAMACHY-mission objectives and measurement modes, J. Atmos. Sci., 56, 127-150, 1999.

Bowman, K. P.: Transport of carbon monoxide from the tropics to the extratropics, J. Geophys. Res., 111, D02107, doi:10.1029/2005JD006137, 2006.

Buchwitz, M., Noël, S., Bramstedt, K., Rozanov V. V., Eisinger, M., Bovensmann, H., Tsvetkova, S., and Burrows, J. P.: Retrieval of trace gas vertical columns from SCIAMACHY/ENVISAT nearinfrared nadir spectra: First preliminary results, Adv. Space Res., 34, 809-814, 2004.

Burrows, J. P., Weber, M., Buchwitz, M., Rozanov, V.: LadstätterWeißenmayer, A., Richter, A., DeBeek, R., Hoogen, R., Bramstedt, K., Eichmann, K. -U., Eisinger, M., and Perner, D.: The Global Ozone Monitoring Experiment (GOME): Mission concept and first scientific results, J. Atmos. Sci., 56, 151-175, 1999.

Chipperfield, M. P.: Multiannual Simulations with a ThreeDimensional Chemical Transport Model, J. Geophys. Res., 104, 1781-1805, 1999.

Dentener, F., van Weele, M., Krol M., Houweling S., and van Velthoven P.: Trends and inter-annual variability of methane emissions derived from 1979-1993 global CTM simulations, Atmos. Chem. Phys., 3, 73-88, 2003,

http://www.atmos-chem-phys.net/3/73/2003/.

Dufour, G., Boone, C. D., Rinsland, C. P., and Bernath, P. F.: First space-borne measurements of methanol inside aged tropical biomass burning plumes using the ACE-FTS instrument, Atmos. Chem. Phys., 6, 3463-3470, 2006,

http://www.atmos-chem-phys.net/6/3463/2006/.

Dunlea, E. J., Herndon, S. C., Nelson, D. D., Volkamer, R. M., San Martini, F., Sheehy, P. M., Zahniser, M. S., Shorter, J. H., Wormhoudt, J. C., Lamb, B. K., Allwine, E. J., Gaffney, J. S., Marley, N. A., Grutter, M., Marquez, C., Blanco, S., Cardenas, B., Retama, A., Ramos Villegas, C. R., Kolb, C. E., Molina, L. T., and Molina, M. J.: Evaluation of nitrogen dioxide chemiluminescence monitors in a polluted urban environment, Atmos. Chem. Phys., 7, 2691-2704, 2007,

http://www.atmos-chem-phys.net/7/2691/2007/.

EFMA (European Fertilizer Manufacturers Association): Forecast of food, farming and fertilizer use in European Union 20052015, Brussels, 2005.

Efron, B. and Tibshirani, R. J.: An introduction to the bootstrap, New York, Chapman \& Hall, 1993.

Eisinger, M. and Burrows, J. P.: Tropospheric Sulfur Dioxide observed by the ERS-2 GOME instrument, Geophys. Res. Lett., 25, 4177-4180, 1998.

Enting, I. G.: Inverse problems in atmospheric constituents transport, Cambridge University Press, 2002.

FAO (Food and Agriculture organization of United Nations): Current world fertilizer trends and outlook 20 2008/09, Rome, 2004

GENEMIS (Generation of European Emission Data for Episodes) project: EUROTRAC Annual Report 1993, Part 5, EUROTRAC International Scientific Secretariat, Garmisch-Partenkirchen, Germany, 1994.

Guenther, A., Hewitt, C. N., Erickson, D., Fall, R., Geron, C., Graedel, T., Harley, P., Klinger, L., Lerdau, M., McKay, W. A., Pierce, T., Scholes, B., Steinbrecher, R., Tallamraju, R., Taylor, J., and Zimmerman, P.: A global model of natural volatileorganic compound emissions, J. Geophys. Res., 100, 8873-8892, 1995. 
Horowitz, L. W., Walters, S., Mauzerall, D. L., et al.: A global simulation of ozone and related tracers: description and evaluation of MOZART, Version 2, J. Geophys. Res., 108(D24), 4784, doi:10.1029/2002JD002853, 2003.

Jaeglé, L., Martin, R. V., Chance, K., Steinberger, L., Kurosu, T. P., Jacob, D. J., Modi, A. I., Yoboué, V., Sigha-Nkamdjou, L., and Galy-Lacaux, C.: Satellite mapping of rain-induced nitric oxide emissions from soils, J. Geophys. Res., 109, D21310, doi:10.1029/2004JD004787, 2004.

Jonson, J. E., Simpson, D., Fagerli, H., and Solberg, S.: Can we explain the trends in European ozone levels?, Atmos. Chem. Phys., 6, 51-66, 2006, http://www.atmos-chem-phys.net/6/51/2006/.

Kim, S.-W., Heckel, A., McKeen, S. A., Frost, G. J., Hsie, E.-Y., Trainer, M. K., Richter, A., Burrows, J. P., Peckham, S. E., and Grell, G. A.: Satellite-observed U.S. power plant $\mathrm{NO}_{\mathrm{x}}$ emission reductions and their impact on air quality, Geophys. Res. Lett., 33, L22812, doi:10.1029/2006GL027749, 2006.

Konovalov, I. B., Beekmann, M., Vautard, R., Burrows, J. P., Richter, A., Nüß, H., and Elansky, N.: Comparison and evaluation of modelled and GOME measurement derived tropospheric $\mathrm{NO}_{2}$ columns over Western and Eastern Europe, Atmos. Chem. Phys., 5, 169-190, 2005,

http://www.atmos-chem-phys.net/5/169/2005/.

Konovalov, I. B., Beekmann, M., Richter, A., and Burrows, J. P.: Inverse modelling of the spatial distribution of $\mathrm{NO}_{\mathrm{x}}$ emissions on a continental scale using satellite data, Atmos. Chem. Phys., 6, 1747-1770, 2006a,

http://www.atmos-chem-phys.net/6/1747/2006/.

Konovalov, I. B., Beekmann, M., Richter, A., and Burrows, J. P.: The use of satellite and ground based measurements for estimating and reducing uncertainties in the spatial distribution of emissions of nitrogen oxides, arXiv: physics/0612144 (www.arxiv.org), 2006b.

Leue, C., Wenig, M., Wagner, T., Klimm, O., Platt, U., and Jahne, B.: Quantitative analysis of $\mathrm{NO}_{\mathrm{x}}$ emissions from GOME satellite image sequences, J. Geophys. Res., 106, 5493-5505, 2001.

Martin, R. V., Jacob, D. J., Chance K., Kurosu, T., Palmer P. I., and Evans, M. J.: Global inventory of nitrogen oxide emissions constrained by space-based observations of $\mathrm{NO}_{2}$ columns, J. Geophys. Res., 108, 4537, doi:10.1029/2003JD003453, 2003.

Martin, R. V., Sioris, C. E., Chance, K., Ryerson, T. B., Bertram, T. H., Wooldridge, P. J., Cohen, R. C., Neuman, J. A., Swanson, A., and Flocke, F. M.: Evaluation of space-based constraints on global nitrogen oxide emissions with regional aircraft measurements over and downwind of eastern North America, J. Geophys. Res., 111, D15308, doi:10.1029/2005JD006680, 2006.

Martin, R. V., Sauvage, B., Folkins, I., Sioris, C. E., Boone, C., Bernath, P., and Ziemke, J.: Space-based constraints on the production of nitric oxide by lightning, J. Geophys. Res., 112, D09309, doi:10.1029/2006JD007831, 2007.

Millet, D. B., Jacob, D. J., Turquety, S., Hudman, R. C., Wu, S., Fried, A., Walega, J., Heikes, B. G., Blake, D. R., Singh, H. B., Anderson, B. E., and Clarke; A. D.: Formaldehyde distribution over North America: Implications for satellite retrievals of formaldehyde columns and isoprene emission, J. Geophys. Res., 111, D24S02, doi:10.1029/2005JD006853, 2006.

Müller, J.-F. and Stavrakou, T.: Inversion of $\mathrm{CO}$ and $\mathrm{NO}_{\mathrm{x}}$ emissions using the adjoint of the IMAGES model, Atmos. Chem. Phys., 5,
1157-1186, 2005,

http://www.atmos-chem-phys.net/5/1157/2005/.

Ordonez, C., Brunner, D., Staehelin, J., Hadjinicolaou, P., Pyle, A., Jonas, M., Wernli, H., and Prevot, A. S. H.: Strong influence of lowermost stratospheric ozone on lower tropospheric background ozone changes over Europe, Geophys. Res. Lett., 34, L07805, doi:10.1029/2006GL029113, 2007.

Palmer, P. I., Jacob, D. J., Chance, K., Martin, R. V., Spurr, R. J. D., Kurosu, T. P., Bey, I., Yantosca, R., Fiore, A., and Li, Q. B.: Air mass factor formulation for spectroscopic measurements from satellites: Application to formaldehyde retrievals from the Global Ozone Monitoring Experiment, J. Geophys. Res., 106, 14 539-14 550, 2001.

Palmer, P. I., Jacob, D. J., Fiore, A., Martin, R. V., Chance, K., and Kurosu, T. P.: Mapping isoprene emissions over North America using formaldehyde column observations from space, J. Geophys. Res., 108(D6), 4180, doi:10.1029/2002JD002153, 2003.

Pétron, G., Granier, C., Khattatov, B., Yudin, V., Lamarque, J.-F., Emmons, L., Gille, J., and Edwards, D. P.: Monthly CO surface sources inventory based on the 20002001 MOPITT satellite data: Geophys. Res. Lett., 31, L21107, doi:10.1029/2004GL020560, 2004.

Richter, A. and Burrows, J. P.: Tropospheric $\mathrm{NO}_{2}$ from GOME measurements, Adv. Space Res., 29, 1673-1683, 2002.

Richter, A., Eyring, V., Burrows, J. P., Bovensmann, H., Lauer, A. Sierk, B., and Crutzen, P. J.: Satellite Measurements of $\mathrm{NO}_{2}$ from International Shipping Emissions, Geophys. Res. Lett., 31, L23110, doi:10.1029/2004GL020822, 2004.

Richter, A., Burrows, J. P., Nüß, H., Granier, C., and Niemeier, U.: Increase in Tropospheric Nitrogen Dioxide Over China Observed from Space, Nature, 437, 129-132, doi:10.1038/nature04092, 2005.

Schmidt, H. C., Derognat, C., Vautard, R., and Beekmann, M.: A comparison of simulated and observed ozone mixing ratios for the summer of 1998 in western Europe, Atmos. Environ., 35, 6277-6297, 2001.

Simmonds, P. G., Derwent, R. G., Manning, A. L., and Spain, G.: Significant growth in surface ozone at MaceHead, Ireland, 19872003, Atmos. Environ., 38, 4769-4778, 2005.

Simpson, D., Winiwarter, W., Borjesson, G., Cinderby, S., Ferreiro, A., Guenther, A., Hewitt, C. N., Janson, R., Khalil, M. A. K., Owen, S., Pierce, T. E., Puxbaum, H., Shearer, M., Steinbrecher, S., Svennson, B. H., Tarrason, L., and Oquist, M. G.: Inventorying emissions from nature in Europe, J. Geophys. Res., 104, 8113-8152, 1999.

Stavrakou, T. and Müller, J.-F.: Grid-based versus big region approach for inverting $\mathrm{CO}$ emissions using Measurement of Pollution in the Troposphere (MOPITT) data, J. Geophys. Res., 111, D15304, doi:10.1029/2005JD006896, 2006.

Steinbacher, M., Zellweger, C., Schwarzenbach, B., Bugmann, S., Buchmann, B., Ordóñez, C., Prevot, A. S. H., and Hueglin, C.: Nitrogen oxide measurements at rural sites in Switzerland: Bias of conventional measurement techniques, J. Geophys. Res., 112, D11307, doi:10.1029/2006JD007971, 2007.

Stohl, A., Williams, E., Wotawa, G., and Kromp-Kolb, H.: A European inventory of soil nitric oxide emissions on the photochemical formation of ozone in Europe, Atmos. Environ., 30, 37413755, 1996.

van der A, R. J. M, Peters, D. H. M. U., Eskes, H., Boersma, 
K. F., Van Roozendael M., De Smedt, I., and Kelder, H. M.: Detection of the trend and seasonal variation in tropospheric $\mathrm{NO}_{2}$ over China, J. Geophys. Res., 111, D12317, doi:10.1029/2005JD006594, 2006.

Vautard, R., Szopa, S., Beekmann, M., Menut, L., Hauglustaine, D. A., Rouil, L., and Roemer, M.: Are decadal anthropogenic emission reductions in Europe consistent with surface ozone observations?, Geophys. Res. Lett., 33, L13810, doi:10.1029/2006GL026080, 2006.

Velders, G. J. M., Granier, C., Portmann, R. W., Pfeilsticker, K., Wenig, M., Wagner, T., Platt, U., Richter, A., and Burrows, J. P.: Global tropospheric $\mathrm{NO}_{2}$ column distributions: Comparing 3-D model calculations with GOME measurements, J. Geophys. Res., 106, 12 643-12 660, 2001.

Vestreng, V., Breivik, K., Adams, M., Wagener, A., Goodwin, J., Rozovskkaya, O., and Pacyna, J. M.: Inventory Review 2005, Emission Data reported to LRTAP Convention and NEC Directive, Initial review of HMs and POPs, Technical report MSC-W 1/2005, ISSN 0804-2446, 2005.
Wang, Y., McElroy, M. B., Martin, R. V., Streets, D. G., Zhang, Q., and Fu, T.-M.: Seasonal variability of $\mathrm{NO}_{\mathrm{x}}$ emissions over east China constrained by satellite observations: Implications for combustion and microbial sources, J. Geophys. Res., 112, D06301, doi:10.1029/2006JD007538, 2007.

Wittrock, F., Richter, A., Oetjen, H., Burrows, J. P., Kanakidou, M., Myriokefalitakis, S., Volkamer, R., Beirle, S., Platt, U., and Wagner, T.: Simultaneous global observations of glyoxal and formaldehyde from space: Geophys. Res. Lett., 33, L16804, doi:10.1029/2006GL026310, 2006.

Yurganov, L. N., Duchatelet, P., Dzhola, A. V., Edwards, D. P., Hase, F., Kramer, I., Mahieu, E., Mellqvist, J., Notholt, J., Novelli, P. C., Rockmann, A., Scheel, H. E., Schneider, M., Schulz, A., Strandberg, A., Sussmann, R., Tanimoto, H., Velazco, V., Drummond, J. R., and Gille, J. C.: Increased Northern Hemispheric carbon monoxide burden in the troposphere in 2002 and 2003 detected from the ground and from space, Atmos. Chem. Phys., 5, 563-573, 2005,

http://www.atmos-chem-phys.net/5/563/2005/. 